\title{
Fucoxanthin and Colorectal Cancer Prevention
}

\author{
Masaru Terasaki ${ }^{1,2, *}$, Atsuhito Kubota ${ }^{1}$, Hiroyuki Kojima ${ }^{1,2}$, Hayato Maeda ${ }^{3}{ }^{\circ}$, Kazuo Miyashita ${ }^{4}$, \\ Chikara Kawagoe ${ }^{5}$, Michihiro Mutoh ${ }^{6}$ and Takuji Tanaka ${ }^{7}$ (i)
}

1 School of Pharmaceutical Sciences, Health Sciences University of Hokkaido, 1757 Kanazawa, Ishikari-Tobetsu, Hokkaido 061-0293, Japan; atsuhito_k@hoku-iryo-u.ac.jp (A.K.); hirokojima@hoku-iryo-u.ac.jp (H.K.)

2 Advanced Research Promotion Center, Health Sciences University of Hokkaido, 1757 Kanazawa, Ishikari-Tobetsu, Hokkaido 061-0293, Japan

3 Faculty of Agriculture and Life Science, Hirosaki University, 3 Bunkyo-cho, Hirosaki, Aomori 036-8561, Japan; hayatosp@hirosaki-u.ac.jp

4 Center for Industry-University Collaboration, Obihiro University of Agriculture and Veterinary Medicine, Inada-cho, Obihiro, Hokkaido 080-8555, Japan; miyashitak@obihiro.ac.jp

5 Algatech Kyowa, Kyowa Concrete Industry Co. Ltd., Hakodate, Hokkaido 040-0051, Japan; kawagoe.c@kyowa-concrete.co.jp

6 Department of Molecular-Targeting Prevention, Graduate School of Medical Science, Kyoto Prefectural University of Medicine, Kawaramachi-Hirokoji, Kamigyo-ku, Kyoto 602-856, Japan; mimutoh@koto.kpu-m.ac.jp

7 Department of Diagnostic Pathology and Research Center of Diagnostic Pathology, Gifu Municipal Hospital, 7-1 Kashima-cho, Gifu 500-8513, Japan; takutt@gmhosp.gifu.gifu.jp

* Correspondence: terasaki@hoku-iryo-u.ac.jp; Tel.: +81-133-23-1211

Citation: Terasaki, M.; Kubota, A.; Kojima, H.; Maeda, H.; Miyashita, K.; Kawagoe, C.; Mutoh, M.; Tanaka, T. Fucoxanthin and Colorectal Cancer Prevention. Cancers 2021, 13, 2379. https://doi.org/10.3390/ cancers13102379

Academic Editors: Giovanna Caderni and Giovanna Masala

Received: 9 April 2021

Accepted: 10 May 2021

Published: 14 May 2021

Publisher's Note: MDPI stays neutral with regard to jurisdictional claims in published maps and institutional affiliations.

Copyright: (c) 2021 by the authors. Licensee MDPI, Basel, Switzerland. This article is an open access article distributed under the terms and conditions of the Creative Commons Attribution (CC BY) license (https:// creativecommons.org/licenses/by/ $4.0 /)$.
Simple Summary: Colorectal cancer (CRC) is suggested to be preventable by certain food intakes. Fucoxanthin $(\mathrm{Fx})$ is an anticancer agent contained abundantly in edible brown algae. However, epidemiological studies, in vivo and in vitro experiments for CRC, using Fx and Fx-rich foods, have not been fully outlined. To date, it has been reported that $\mathrm{Fx}$, its metabolite of fucoxanthinol $(\mathrm{FxOH})$ and Fx-rich algal extracts exerted anticancer potentials in human CRC cell lines, their cancer stem-cells-like spheroids and CRC animal models through a number of molecular mechanisms. Moreover, many in vivo experiments and interventional human trials have demonstrated that Fx, Fx-rich algal extracts and brown alga itself may improve CRC and/or certain risks, such as obesity, diabetes, metabolic syndrome, inflammation, oxidation, tumor microenvironment and/or gut microbiota. This review is the first report that summarizes the improving effects by $\mathrm{Fx}, \mathrm{FxOH}$ and its rich brown algae for $\mathrm{CRC}$ and the risk factors.

Abstract: Colorectal cancer (CRC), which ranks among the top 10 most prevalent cancers, can obtain a good outcome with appropriate surgery and/or chemotherapy. However, the global numbers of both new cancer cases and death from CRC are expected to increase up to 2030. Diet-induced lifestyle modification is suggested to be effective in reducing the risk of human CRC; therefore, interventional studies using diets or diet-derived compounds have been conducted to explore the prevention of CRC. Fucoxanthin (Fx), a dietary carotenoid, is predominantly contained in edible brown algae, such as Undaria pinnatifida (wakame) and Himanthalia elongata (Sea spaghetti), which are consumed particularly frequently in Asian countries but also in some Western countries. Fx is responsible for a majority of the anticancer effects exerted by the lipophilic bioactive compounds in those algae. Interventional human trials have shown that $\mathrm{Fx}$ and brown algae mitigate certain risk factors for $\mathrm{CRC}$; however, the direct mechanisms underlying the anti-CRC properties of Fx remain elusive. Fx and its deacetylated type "fucoxanthinol" (FxOH) have been reported to exert potential anticancer effects in preclinical cancer models through the suppression of many cancer-related signal pathways and the tumor microenvironment or alteration of the gut microbiota. We herein review the most recent studies on $\mathrm{Fx}$ as a potential candidate drug for CRC prevention.

Keywords: fucoxanthin; colorectal cancer; cancer prevention; carotenoid; tumor microenvironment; gut microbiota 


\section{Introduction}

Colorectal cancer (CRC) is a major global cancer, accounting for about $6 \%$ of total cases of new cancer (1.1 million per 18.1 million) and cancer death (0.6 million per 9.6 million), as estimated by the GLOBOCAN 2018 database [1]. The incidence and mortality of CRC have been declining in highly developed countries, such as the USA, Australia, Russia and Japan, where an early diagnosis, surgical resection and drug treatments are easy to receive. However, both the global incidence and mortality of CRC are expected to increase by 2030 due to an increasing trend in the CRC burden in many other countries [2].

The diagnosed types of CRC typically include CRC derived from polyp and inflammatory bowel disease (IBD)-derived CRC, with a low incidence of hereditable CRCs, such as Lynch syndrome (about $2-4 \%$ ), familial adenomatous polyposis (FAP, about $1 \%$ ), PeutzJeghers syndrome and MUTYH-associated polyposis [3]. The 5-year survival rate in CRC is $60-68 \%$ with racial diversity in all stages; the survival rate is about $90 \%$ when CRC is detected at an early stage before spreading [3]. Convincing and probable risk factors for CRC are as follows: IBD, Lynch syndrome, FAP, Peutz-Jeghers syndrome, MUTYHassociated polyposis, processed meat, alcoholic drinks, body fatness, adult attained height and red meat [4-8]. The key triggers involved in human colorectal carcinogenesis are high frequencies of gene mutations (e.g., adenomatous polyposis coli (APC), Kirsten-ras (KRAS), and TP53) and gene fusions, aberrant expressions of mRNA, micro RNA and long non-coding RNA, alterations of splicing event, core signal transduction, DNA repair, extracellular matrix construction and metabolism, microsatellite instability, hypermethylation, copy number variation, immune dysregulation and gut microbiota alteration [9-15]. Pathological diagnoses have revealed that $\mathrm{CRC}$ arises through multistep carcinogenesis from dysplastic crypts to adenocarcinoma. Mutated APC, KRAS, and TP53 are strongly associated with the malignant progression of CRC [16-19]. In addition, the formation of immunosuppressive tumor microenvironment (TME) is essential for the onset of adenocarcinoma in colorectal mucosal tissue. The colorectal TME is composed of colorectal cancer stem cells (CCSCs), cancer-associated fibroblasts (CAFs), many immune cells, including tumor-associated macrophages (TAMs) and dendritic cells (DCs), modified extracellular matrix (ECM), stromal collagen enhancement and abnormal neovessels [20-22].

Fucoxanthin (Fx, Figure 1), a non-provitamin A carotenoid, is found abundantly in brown algae and microalgae. Fx binds the chlorophyll a/c-protein and contributes to efficient light harvesting for photosynthetic organisms as well as the body color. Fx has been estimated to account for $>10 \%$ of total biogenic carotenoids [23]. It has an unusual allenic bond and a 5,6-monoepoxide, and its molecular weight is $658.9 \mathrm{~g} / \mathrm{mol}$ $\left(\mathrm{C}_{42} \mathrm{H}_{58} \mathrm{O}_{6}\right)$. Fx has been cleared as a safe carotenoid without any adverse effects at $0.5 \%$ $(w / v)$ on human skin and at 20-2000 $\mathrm{mg} \mathrm{Fx} / \mathrm{kg}$ body weight (BW) in rodents [24-26]. Fx is easily metabolized to cis-Fx, fucoxanthinol ( $\mathrm{FxOH}$, Figure 1 ) in the intestine and then to amarouciaxanthin $\mathrm{A}(\mathrm{Amx} \mathrm{A})$ and cis-Amx $\mathrm{A}$ in the liver. $\mathrm{FxOH}$ and cis- $\mathrm{FxOH}$ occur as the main plasma metabolites of human-ingested brown algae or its extract $[27,28]$. Hashimoto et al. showed that a single administration of an algal extract ( $31 \mathrm{mg} \mathrm{Fx}$ ) resulted in a maximum concentration of $44.2 \mathrm{nmol} / \mathrm{l}$, time at maximum concentration of $4.0 \mathrm{~h}$ and terminal half-life of $7.0 \mathrm{~h}$ for plasma $\mathrm{FxOH}$ [28]. In contrast, $\mathrm{FxOH}, \mathrm{Amx} \mathrm{A}$ and cis-Amx A are the predominant forms in the blood and various organs of mice administered Fx [29,30]. Several early studies have shown that Fx exerts important anti-inflammation [31], antiobesity [32], anti-diabetes [33], anti-hypertension [34], anti-cardiovascular diseases [34], antimicrobial [35], antioxidation [36], photoprotection [37], anti-angiogenesis [38], antibrain injury $[39,40]$ and anticancer $[41,42]$ effects in human, animal models and culture cells. 
A

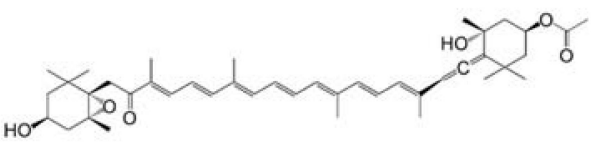

Fucoxanthin (Fx)

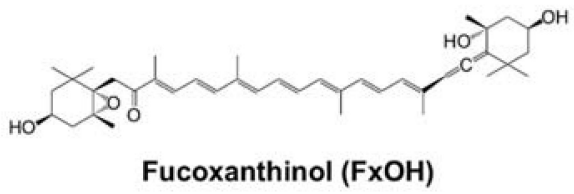

B

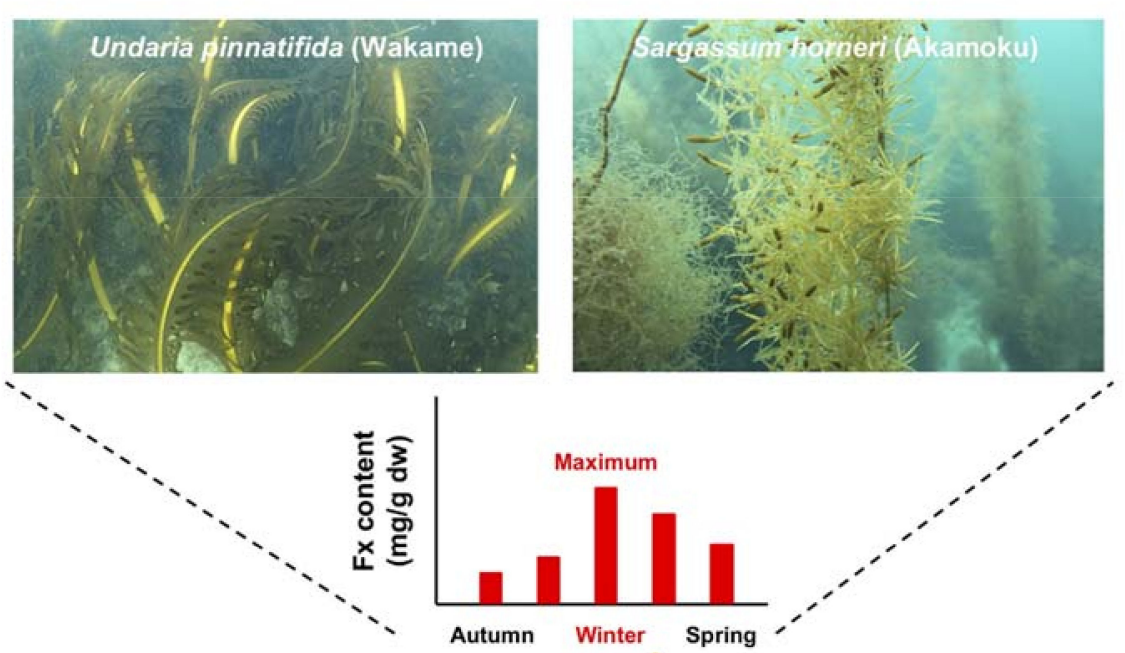

Fx additive materials prepared from brown algae and microalgae

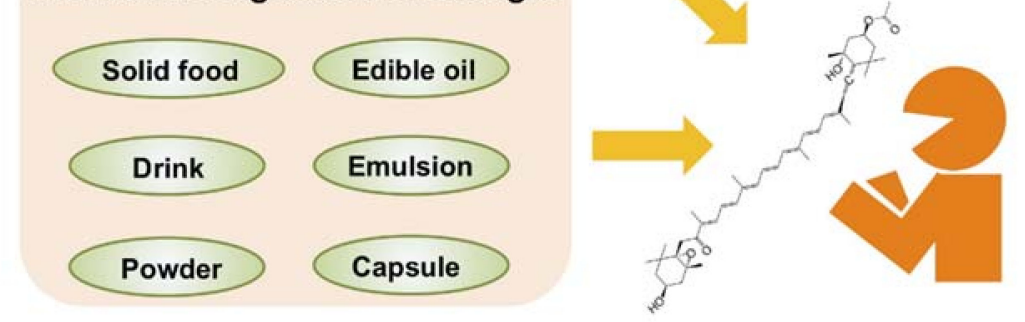

Figure 1. Ingestible routes of Fx in humans. (A) Chemical structures of fucoxanthin (Fx) and fucoxanthinol (FxOH). (B) Ingestible routes of Fx in humans. Whole brown algae, such as Undaria pinnatifida (Wakame) and Sargassum horneri (Akamoku), collected in the winter, when the content of Fx is the highest, may be beneficial for human health. Furthermore, Fx extracted from brown algae and microalgae can be added to various edible items to customize their route of ingestion by humans.

Although many epidemiological studies have been conducted on nutritional approaches to CRC prevention, carotenoids-particularly non-polar carotenoids, such as $\alpha$-carotene, $\beta$-carotene and lycopene-are still ranked as having limited evidence or no conclusion. However, carotenoids are abundantly contained in vegetables and fruits whose effects on CRC prevention are described as limited evidence to suggestive [8]. Furthermore, the effects of carotenoids vary widely depending on the polarity and include Fx, neoxanthin, violaxanthin, $\beta$-cryptoxanthin and lutein, $\alpha$-carotene, $\beta$-carotene and lycopene. To date, epidemiological studies involving in vivo and in vitro experiments for CRC, using Fx itself and its rich foods, have not been fully outlined.

We herein review the most recent studies on $\mathrm{Fx}$ as a potential CRC preventive agent. There is little information available on a direct evidence of anti-CRC properties of Fx for patients; however, $\mathrm{Fx}$ and $\mathrm{FxOH}$ have been reported to exert potential anticancer effects in many CRC cell lines (summarized in Section 3), as well as in many preclinical CRC animal models (summarized in Section 4). In addition, many interventional human trials and in vivo studies have suggested that $\mathrm{Fx}$ and its rich brown algae may improve CRC and/or certain risks for CRC such as obesity, diabetes, metabolic syndrome, inflammation, oxidation, TME, and gut microbiota (summarized in Sections 4 and 5). This is the first 
report integrated the improving effects by Fx and its rich brown algae for CRC and the risk factors.

\section{Fx Sources in Foods and Other Materials}

Brown algae, such as Heterokontophyta and Ochrophyta, are traditionally and most widely consumed in Asian countries, such as Japan, China and Korea [43]. However, brown algae are expanding steadily as novel foods in North America, South America and Europe [44]. The European market, in particular, is one of the most rapidly growing regions regarding the consumption of brown algae $[45,46]$.

Four brown algae species-Undaria pinnatifida (Wakame), Sargassum horneri (Akamoku), Hizikia fusiforme (Hiziki) and Saccharina japonica (Makombu)—are habitually consumed as representative seafood sources in Asia. In Europe, nine species of edible brown algaeFucus vesiculosus, Fucus serratus, Himanthalia elongata (Sea spaghetti), U. pinnatifida, Ascophyllum nodosum, Laminaria digitate, Laminaria saccharina, Saccharina japonica and Alaria esculenta-are generally consumed [47].

Data on the collection site and Fx content of 24 major brown algae are presented in Table 1 [48-65]. The Fx profile of $U$. pinnatifida has been investigated by many researchers worldwide. Among these reports, seasonal variations in Fx content have been well observed in U. pinnatifida collected from Japan, New Zealand and Australia: Japan, 0.3-5.3 mg Fx/g dry weight (dw); New Zealand, 0.8-6.2 mg Fx/g dw; Australia, 2.1-3.0 mg $\mathrm{Fx} / \mathrm{g} \mathrm{dw}$ in juvenile and 1.3-2.9 $\mathrm{mg} \mathrm{Fx} / \mathrm{g} \mathrm{dw}$ in adult sporophytes [48,50-53]. The highest Fx content in $U$. pinnatifida was observed in the winter in Japan, New Zealand and Australia. Furthermore, the Fx content of S. horneri peaked at $10.8 \mathrm{mg} \mathrm{Fx} / \mathrm{g} \mathrm{dw}$ in winter in Japan [50]. Moreover, although the collection period was unknown, the Fx level of H. elongata was surprisingly high at $18.6 \mathrm{mg} \mathrm{Fx} / \mathrm{g} \mathrm{dw}$ [62]. In general, the winter season, which is characterized by low levels of both sunshine duration and seawater temperature, facilitates increased Fx production in brown algae through the xanthophyll-cycle pathway, involving the formation of Fx by upstream carotenoids $[66,67]$. These results suggest that $U$. pinnatifida, S. horneri and H. elongata collected in the winter period may be particularly good sources of Fx for human consumption (Figure 1).

While Fx can be synthesized chemically, the harmless extraction of Fx from biological materials is extremely promising from the perspective of accessibility, economy, environmental load and safety for food additive, cosmetic and pharmaceutical applications. When obtaining Fx through natural extraction, not only brown algae but also microalgae are convenient for use in the large-scale preparation of various materials requiring Fx addition. For instance, the Fx levels of Mallomonas sp. SBV13, Phaeodactylum tricornutum, Odontella aurita and Isochrisis affinis galbana, all microalgae, are 26.6, 8.6-24.2, 21.7 and $18.2 \mathrm{mg} / \mathrm{g}$ $\mathrm{dw}$, respectively [68-70]. Edible oil-, emulsion- or encapsulation-based Fx products in addition to pure Fx powder have been successfully commercialized worldwide. Their Fx-loading materials correspond to the protective shell are good options for achieving high bioavailability and health benefits of Fx in humans compared with a free body of Fx powder that get easily be degraded by light, temperature and oxidation. Edible oils, such as palm, olive and soybean oils, have low toxicity for humans and are often used to the extraction of Fx from brown algae or microalgae [71]. Long- and medium-chain triacylglycerols (TAGs), indigestible oils, Arabic gum and lecithin are frequently used as emulsifiers of Fx. Encapsulation has been constructed by the individual or combination with proteins, oligosaccharides, polysaccharides or glycolipids [72].

Many researchers have described the stability and functional properties of Fx-incorporated drinks, edible oils and foods [73-77]. Taken together, these findings suggest that the ingestion approaches of Fx for humans include not just plain brown algae but also Fx-incorporated products intended for human health benefits (Figure 1). 
Table 1. Fucoxanthin content in 24 major edible brown algae worldwide.

\begin{tabular}{|c|c|c|c|c|c|c|c|}
\hline Family & Species & $\begin{array}{l}\text { Common } \\
\text { Name }\end{array}$ & $\begin{array}{c}\text { Synonym } \\
\text { Name }\end{array}$ & $\begin{array}{l}\text { Collected } \\
\text { Location }\end{array}$ & $\begin{array}{c}\text { Body Part } \\
\text { of Alga }\end{array}$ & $\begin{array}{c}\text { Fx } \\
(\mathrm{mg} / \mathrm{g} d w)^{a}\end{array}$ & Reference \\
\hline \multirow{5}{*}{ Alariaceae } & \multirow{3}{*}{$\begin{array}{c}\text { Undaria } \\
\text { pinnatifida }\end{array}$} & \multirow{3}{*}{ Wakame } & & Japan & Blade & $0.3-5.3$ & {$[48,50,51]$} \\
\hline & & & & New Zealand & Blade & $0.8-6.2$ & [52] \\
\hline & & & & Australia & $-^{\mathrm{b}}$ & $1.3-3.0$ & [53] \\
\hline & $\begin{array}{c}\text { Alaria } \\
\text { esculenta }\end{array}$ & Dabberlocks & & Ireland & Blade & 0.9 & [54] \\
\hline & $\begin{array}{c}\text { Alaria } \\
\text { crassifolia }\end{array}$ & Chigaiso & & Japan & Blade & 1.1 & [49] \\
\hline \multirow[t]{8}{*}{ Sargassaceae } & $\begin{array}{l}\text { Sargassum } \\
\text { horneri }\end{array}$ & Akamoku & & $\begin{array}{l}\text { Japan } \\
\text { Korea }\end{array}$ & $\begin{array}{l}\text { Lateral } \\
\text { branch } \\
-\end{array}$ & $\begin{array}{c}0.8-10.8 \\
0.8\end{array}$ & $\begin{array}{c}{[49,50]} \\
{[55]}\end{array}$ \\
\hline & $\begin{array}{l}\text { Sargassum } \\
\text { fusiforme }\end{array}$ & Hiziki & & Japan & $\begin{array}{l}\text { Lateral } \\
\text { branch }\end{array}$ & 1.1 & [49] \\
\hline & $\begin{array}{l}\text { Sargassum } \\
\text { wightii }\end{array}$ & & & India & - & 0.1 & [56] \\
\hline & $\begin{array}{l}\text { Sargassum } \\
\text { binderi }\end{array}$ & & & India & - & 0.7 & [57] \\
\hline & $\begin{array}{l}\text { Sargassum } \\
\text { duplicatum }\end{array}$ & & & India & - & 1.0 & [57] \\
\hline & $\begin{array}{c}\text { Nizamuddinia } \\
\text { zanardinii }\end{array}$ & & & Iran & - & $0.6-1.7$ & [58] \\
\hline & $\begin{array}{l}\text { Cystoseira } \\
\text { indica }\end{array}$ & & & Iran & - & $2.3-3.6$ & [58] \\
\hline & $\begin{array}{c}\text { Turbinaria } \\
\text { ornata }\end{array}$ & & & Indonesia & - & 1.3 & [59] \\
\hline \multirow{6}{*}{ Laminariaceae } & \multirow{3}{*}{$\begin{array}{l}\text { Saccharina } \\
\text { japonica }\end{array}$} & \multirow{3}{*}{ Makombu } & \multirow{3}{*}{$\begin{array}{l}\text { Laminalia } \\
\text { japonica }\end{array}$} & Japan & - & 0.2 & {$[60]$} \\
\hline & & & & China & - & 0.4 & {$[61]$} \\
\hline & & & & Korea & - & 0.5 & [55] \\
\hline & $\begin{array}{l}\text { Saccharina } \\
\text { sculpera }\end{array}$ & Gagomekombu & $\begin{array}{c}\text { Kjellmaniella } \\
\text { crassifolia, } \\
\text { Saccharina } \\
\text { crassifolia }\end{array}$ & Japan & $\begin{array}{l}\text { Lateral } \\
\text { branch }\end{array}$ & 0.7 & [49] \\
\hline & $\begin{array}{l}\text { Laminaria } \\
\text { digitata }\end{array}$ & & & Ireland & Blade & 0.7 & [54] \\
\hline & $\begin{array}{l}\text { Laminaria } \\
\text { saccharina }\end{array}$ & $\begin{array}{l}\text { Sugar kelp, } \\
\text { sea belt }\end{array}$ & $\begin{array}{c}\text { Fucus } \\
\text { saccharinus, } \\
\text { Saccharina } \\
\text { latissima }\end{array}$ & Ireland & Blade & 0.5 & [54] \\
\hline Lessoniaceae & $\begin{array}{l}\text { Ecklonia } \\
\text { kurome }\end{array}$ & Kurome & & Japan & Blade & 1.7 & [59] \\
\hline \multirow[t]{3}{*}{ Fucaceae } & $\begin{array}{c}\text { Fucus } \\
\text { vesiculosus }\end{array}$ & sea oak & & Ireland & Blade & 0.7 & [54] \\
\hline & Fucus serratus & $\begin{array}{l}\text { Toothed } \\
\text { wrack }\end{array}$ & & Ireland & Blade & 0.3 & [54] \\
\hline & $\begin{array}{c}\text { Ascophyllum } \\
\text { nodosum }\end{array}$ & Rockweed & & Ireland & Blade & 0.4 & [54] \\
\hline Ralfsiaceae & $\begin{array}{l}\text { Analipus } \\
\text { japonicus }\end{array}$ & Matsumo & & Japan & $\begin{array}{l}\text { Lateral } \\
\text { branch }\end{array}$ & 1.4 & [49] \\
\hline
\end{tabular}


Table 1. Cont.

\begin{tabular}{|c|c|c|c|c|c|c|c|}
\hline Family & Species & $\begin{array}{l}\text { Common } \\
\text { Name }\end{array}$ & $\begin{array}{l}\text { Synonym } \\
\text { Name }\end{array}$ & $\begin{array}{l}\text { Collected } \\
\text { Location }\end{array}$ & $\begin{array}{c}\text { Body Part } \\
\text { of Alga }\end{array}$ & $\begin{array}{c}\text { Fx } \\
(\mathrm{mg} / \mathrm{g} d w)^{a}\end{array}$ & Reference \\
\hline Chordariaceae & $\begin{array}{c}\text { Sphaerotrichia } \\
\text { divaricata }\end{array}$ & Kusamozuku & & Japan & $\begin{array}{l}\text { Whole } \\
\text { body }\end{array}$ & 0.2 & [49] \\
\hline Himanthaliaceae & $\begin{array}{c}\text { Himanthalia } \\
\text { elongata }\end{array}$ & Sea spaghetti & $\begin{array}{c}\text { Fucus elongatus, } \\
\text { Himanthalia } \\
\text { lorea }\end{array}$ & $\begin{array}{l}\text { Ireland } \\
\text { Spain }\end{array}$ & Blade & $\begin{array}{c}0.3-18.6 \\
1.1\end{array}$ & $\begin{array}{c}{[54,62]} \\
{[63]}\end{array}$ \\
\hline Chordariaceae & $\begin{array}{l}\text { Cladosiphon } \\
\text { okamuranus }\end{array}$ & \multicolumn{2}{|c|}{ Okinawamozuku } & Japan & - & 0.3 & {$[64]$} \\
\hline \multirow{2}{*}{ Dictyotaceae } & Padina & & & Malaysia & - & 0.4 & [65] \\
\hline & australis & & & Indonesia & - & 1.3 & [59] \\
\hline
\end{tabular}

a Variations of fucoxanthin (Fx) content in major edible brown algae include seasonal change and different location \{value: minimum-max $\mathrm{mg} / \mathrm{g}$ dry weight $(\mathrm{dw})\} .{ }^{\mathrm{b}}$ The body part for extraction in the alga is unknown.

\section{Effect by Brown Algae and Fx in CRC Cellular Lines}

Many studies have shown an antiproliferative effect and the induction of apoptosis by brown algal extract, $\mathrm{Fx}$ and $\mathrm{FxOH}$ in $\mathrm{CRC}$ cells. It was suggested that ethanol extract of U. pinnatifida sporophyll induced apoptosis in human CRC HCT116 cells with the activation of caspase-3, unlike molecular mechanisms of cell death due to two anticarcinostatic drugs (5-fluorouracil (5-FU) and irinotecan) [78]. Ethanol extract from the brown algae Dictyopteris undulata augmented endoplasmic reticulum stress, abrogated mitochondrial membrane potential and induced apoptosis in human CRC SW480 cells through the enhancement of Bax; active caspase-3, caspase-9 and caspase-12; phosphoPERK; phospho-IRE1; cleaved ATF6; CAAT / enhancer-binding protein-homologous protein; and attenuation of Bcl-2 [79,80]. Furthermore, methanol extract of the brown algae Pylaiella littoralis also had an apoptosis-inducing effect in HT-29 cells, with downregulation of Bcl-2, and upregulations of Bax, active caspase-3, cleaved PARP, phospho-JNK, phospho-ERK and p38 was observed [81]. Ethanol extracts of the two brown algae T. ornata and P. pavonia significantly suppressed the growth of HCT116 cells in a dose-dependent manner [82]. Mhadhebi et al. showed that the organic fraction from Cystoseira sedoides exerted an anti-proliferative effect in human CRC HCT15 cells in a dose-dependent manner $(25-500 \mu \mathrm{g} / \mathrm{mL})$, along with antioxidation and anti-inflammation effects [83]. Our group recently investigated the transcriptome profile and protein expression in human CRC DLD-1 cells with FxOH treatment. FxOH $(5.0 \mu \mathrm{M})$ significantly reduced cell growth and induced apoptosis. Gene hierarchical clustering of the cells revealed a significant difference in 807 genes compared with control cells. The genes belonging to cancerrelated pathways, including the cell cycle, integrin, PI3K/AKT, MAPK, nuclear factor erythroid 2 [NF-E2]-related factor 2 (NRF2), adipogenesis, TGF- $\beta$, signal transducer and activators of transcription (STAT) and wingless/integrated (WNT)/ $\beta$-catenin signals, were remarkably altered. In addition, the protein expression of cyclin D1, cyclin D2, integrin $\alpha 5$, integrin $\beta 1$, phospho-Paxillin $\left(\mathrm{Tyr}^{31}\right.$ ), phospho-AKT(Ser ${ }^{473}$ ), phospho-C-Raf $\left(\operatorname{Ser}^{338}\right)$, phospho-MEK1/2(Ser $\left.{ }^{217 / 221}\right)$, PPAR $\gamma$ and phospho-Smad2(Ser $\left.{ }^{465 / 467}\right)$ was downregulated, while that of phospho-ERK1/2(Thr $\left.{ }^{202} / \mathrm{Tyr}^{204}\right)$ and NRF2 was upregulated [84]. We also demonstrated the suppressive effect of CLIC4 signal and induction of anoikis due to attenuation of an integrin signal by FxOH in DLD-1 cells [85,86]. Tamura et al. showed that $\mathrm{FxOH}$ $(10 \mu \mathrm{M})$ induced apoptosis in HCT116 cells by increasing the NF-kB activity. However, the co-treatment of FxOH and an NF- $\mathrm{kB}$ inhibitor enhanced apoptosis induction [87]. LopesCosta et al. reported that Fx reduced cell viability and induced DNA damage in HCT116 and HT-29 cells, while little apparent effect on normal human colon CCD-18Co cells was observed, except at high concentrations (50 and $100 \mu \mathrm{M})$. This report also showed that $\mathrm{Fx}$ enhanced the cytotoxic effect of 5-FU in HCT116 cells [88]. Fx treatment (50 and $75 \mu \mathrm{M})$ 
induced apoptosis in human CRC WiDr cells through the arrest of the G0/G1 phase of the cell cycle and upregulation of p21 WAF1/Cip1, an inhibitor of cyclin D [89]. Both Fx and $\mathrm{FxOH}$ addition induced apoptosis in human CRC Caco-2 cells. The Bcl-2 protein expression was decreased on cells treated with Fx [90,91]. Fx suppressed cell growth in human CRC SW-620 s via the loss of adhesion and invasion activities and of MMP-9 expression and amplified the 5-FU-induced anti-proliferative effect [92]. Treatment with $\mathrm{FxOH}$ and Fx (both $20 \mu \mathrm{M}$ ) significantly inhibited and tended to inhibit cell growth, respectively, of primary cells isolated from tumor tissue from patients with CRC [93].

CCSCs are involved in the development of CRC and have properties that include selfrenewal, pluripotency, chemotherapy resistance, sphere formation and tumorigenesis [94,95]. Sphere-forming cells prepared by using stem cell medium with slight growth factors from CRC cells, colonospheres (Csps), are known to possess CCSCs-like features [96]. Our previous study demonstrated that $\mathrm{FxOH}$ treatment significantly disintegrated Csps in a dose-dependent manner. In addition, $\mathrm{FxOH}$ downregulated phospho-AKT(Ser ${ }^{473}$ ), PPAR $\beta / \delta$ and PPAR $\gamma$ in the Csps and significantly suppressed subcutaneous tumorigenesis in NOD-SCID (NOD.CB17-Prkdc ${ }^{\text {scid } / J) ~ m i c e ~[97] . ~ F x O H ~ a l s o ~ i n h i b i t e d ~ c e l l ~ m i g r a t i o n ~ a n d ~}$ invasion and induced apoptosis under both normoxia and hypoxia conditions by altering certain signals, including EMT, integrin, MAPK, WNT/ $\beta$-catenin, apoptosis and/or STAT signals $[98,99]$. Similarly, Fx treatment exerted a sphere-forming activity in spheroid prepared from human breast cancer MCF-7 cells, although its molecular mechanisms remain unknown [100]. Further studies are needed to confirm the underlying mechanisms on the suppression of sphere formation in Csps by Fx and FxOH treatments. Table 2 summarizes the molecular mechanisms underlying the effects of brown algae and Fx in human CRC cells.

Table 2. Effect of fucoxanthin (Fx)-rich brown algal extract, Fx and fucoxanthinol (FxOH) in human colorectal cancer cell lines.

\begin{tabular}{|c|c|c|c|c|c|}
\hline $\begin{array}{l}\text { Brown Algal Extract } \\
\text { or Compound } \\
\text { (Additive } \\
\text { Concentration) }\end{array}$ & $\begin{array}{l}\text { Cell Line } \\
\text { (Cell Type) }\end{array}$ & $\begin{array}{l}\text { Promoted Molecular } \\
\text { Mechanism(s) }\end{array}$ & $\begin{array}{l}\text { Involved } \\
\text { Intracellular } \\
\text { Component }\end{array}$ & $\begin{array}{l}\text { Final Outcome } \\
\text { (Cell Function) }\end{array}$ & Reference \\
\hline $\begin{array}{l}\text { Ethanol extract of } \\
\text { Undaria pinnatifida } \\
\text { sporophyll }(\sim 2.0 \%)\end{array}$ & $\begin{array}{l}\text { HCT116 } \\
\text { (PCs) }\end{array}$ & $\begin{array}{l}\text { Caspase-3 activation, and } \\
\text { non-oxidative mechanisms } \\
\text { differed from those of } \\
\text { 5-fluorouracil and irinotecan } \\
\text { treatments }\end{array}$ & NA & Apoptosis & [78] \\
\hline $\begin{array}{l}\text { Ethanol extract of } \\
\text { Dictyopteris undulata } \\
\text { sporophyll } \\
(\sim 200 \mu \mathrm{g} / \mathrm{mL})\end{array}$ & $\begin{array}{l}\text { SW480 } \\
\text { (PCs) }\end{array}$ & $\begin{array}{l}\text { Augmentation of endoplasmic } \\
\text { reticulum stress; attenuation of } \\
\text { mitochondrial membrane } \\
\text { potential; increases of Bax, } \\
\text { caspase-3, caspase-9, caspase-12, } \\
\text { phospho-PERK, phospho-IRE1, } \\
\text { cleaved ATF6, and } \\
\text { CAAT/enhancer-binding } \\
\text { protein-homologous protein; } \\
\text { and decrease of Bcl-2 }\end{array}$ & $\begin{array}{l}\text { Endoplasmic } \\
\text { reticulum, and } \\
\text { mitochondria }\end{array}$ & Apoptosis & {$[79,80]$} \\
\hline $\begin{array}{l}\text { Methanol extract of } \\
\text { Pylaiella littoralis } \\
(\sim 100 \mu \mathrm{g} / \mathrm{mL})\end{array}$ & $\begin{array}{l}\text { HT-29 } \\
\text { (PCs) }\end{array}$ & $\begin{array}{c}\text { Attenuation of mitochondrial } \\
\text { membrane potential, decrease } \\
\text { of Bcl-2, and increases of Bax, } \\
\text { active caspase-3 form, cleaved } \\
\text { PARP, phospho-JNK, } \\
\text { phospho-ERK and p38 }\end{array}$ & Mitochondria & Apoptosis & [81] \\
\hline $\begin{array}{l}\text { Ethanol extracts of } \\
\text { Turbinaria ornata and } \\
\text { Padina pavonia } \\
(\sim 50 \mu \mathrm{g} / \mathrm{mL})\end{array}$ & $\begin{array}{l}\text { HCT116 } \\
\text { (PCs) }\end{array}$ & & NA & Growth inhibition & [82] \\
\hline $\begin{array}{l}\text { Organic fraction of } \\
\text { Cystoseira sedoides } \\
(\sim 500 \mu \mathrm{g} / \mathrm{mL})\end{array}$ & $\begin{array}{l}\text { HCT115 } \\
\text { (PCs) }\end{array}$ & & NA & $\begin{array}{l}\text { Growth inhibition, } \\
\text { antioxidation and } \\
\text { anti-inflammation }\end{array}$ & [83] \\
\hline
\end{tabular}


Table 2. Cont.

\begin{tabular}{|c|c|c|c|c|c|}
\hline $\begin{array}{l}\text { Brown Algal Extract } \\
\text { or Compound } \\
\text { (Additive } \\
\text { Concentration) }\end{array}$ & $\begin{array}{l}\text { Cell Line } \\
\text { (Cell Type) }\end{array}$ & $\begin{array}{l}\text { Promoted Molecular } \\
\text { Mechanism(s) }\end{array}$ & $\begin{array}{l}\text { Involved } \\
\text { Intracellular } \\
\text { Component }\end{array}$ & $\begin{array}{l}\text { Final Outcome } \\
\text { (Cell Function) }\end{array}$ & Reference \\
\hline $\mathrm{FxOH}(\sim 5.0 \mu \mathrm{M})$ & $\begin{array}{l}\text { DLD-1 } \\
\text { (PCs) }\end{array}$ & $\begin{array}{c}\text { Alterations of gene set } \\
\text { belonging cell cycle, integrin, } \\
\text { PI3K/AKT, MAPK, NRF2, } \\
\text { adipogenesis, TGF- } \beta \text {, STAT and } \\
\text { WNT/ } \beta \text {-catenin signals, } \\
\text { decreases of cyclin D1, cyclin } \\
\text { D2, integrin } \alpha 5 \text {, integrin } \beta 1, \\
\text { phospho-Paxillin }\left(\mathrm{Tyr}^{31}\right), \\
\left.\text { phospho-AKT(Ser }{ }^{473}\right), \\
\text { phospho-C-Raf }\left(\mathrm{Ser}^{338}\right), \\
\left.\text { phospho-MEK1/2(Ser }{ }^{217 / 221}\right), \\
\text { PPAR } \gamma \text { and } \\
\left.\text { phospho-Smad2(Ser }{ }^{465 / 467}\right), \\
\text { and increases of phospho- } \\
\left.\text { ERK1/2(Thr }{ }^{202} / \mathrm{Tyr}^{204}\right) \\
\text { and NRF2 }\end{array}$ & NA & Apoptosis & [84] \\
\hline $\mathrm{FxOH}(\sim 5.0 \mu \mathrm{M})$ & $\begin{array}{l}\text { DLD-1 } \\
\text { (PCs) }\end{array}$ & $\begin{array}{c}\text { Arrest of G2/M cell cycle phase, } \\
\text { decreases of CLIC4, integrin } \beta 1, \\
\text { phospho-Smad2(Ser } 465 / 467) \\
\text { and NHERF2 }\end{array}$ & NA & Apoptosis & [85] \\
\hline $\mathrm{FxOH}(\sim 2.5 \mu \mathrm{M})$ & $\begin{array}{l}\text { DLD-1 } \\
\text { (PCs) }\end{array}$ & $\begin{array}{c}\text { Alteration on cellular } \\
\text { distribution of integrin } \beta 1, \\
\text { and decreases of } \\
\text { phospho-FAK }\left(\mathrm{Tyr}^{397}\right) \\
\left.\text { phospho-AKT(Ser }{ }^{473}\right) \\
\text { and PPAR } \gamma\end{array}$ & NA & Anoikis & [86] \\
\hline $\mathrm{FxOH}(\sim 10 \mu \mathrm{M})$ & $\begin{array}{l}\text { HCT116 } \\
\text { (PCs) }\end{array}$ & $\begin{array}{c}\text { Arrest of G0/G1 cell cycle } \\
\text { phase, activations of NF- } \mathrm{kB} \text { and } \\
\text { caspase- } 3 \text {, and increases of } \\
\text { XIAP and cIAP-1 }\end{array}$ & NA & Apoptosis & [87] \\
\hline $\operatorname{Fx}(\sim 100 \mu \mathrm{M})$ & $\begin{array}{l}\text { HCT116 and HT-29 } \\
\text { (Both PCs) }\end{array}$ & $\begin{array}{l}\text { Increase of p53 and decrease of } \\
\text { Bcl-2 in HCT116 cells, and } \\
\text { increase of Bax and decrease of } \\
\text { pro-caspase- } 9 \text { in HT- } 29 \text { cells }\end{array}$ & NA & Growth inhibition & [88] \\
\hline $\mathrm{Fx}(\sim 75 \mu \mathrm{M})$ & WiDr & 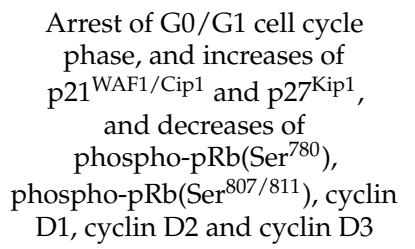 & NA & Apoptosis & [89] \\
\hline $\operatorname{Fx}(\sim 15.2 \mu \mathrm{M})$ & Caco-2 & $\begin{array}{c}\text { Decrease of Bcl-2 and activation } \\
\text { of caspases }\end{array}$ & NA & Apoptosis & [90] \\
\hline $\mathrm{FxOH}(\sim 25 \mu \mathrm{M})$ & Caco-2 & & NA & Growth inhibition & [91] \\
\hline $\mathrm{Fx}(\sim 30 \mu \mathrm{M})$ & SW-620 & $\begin{array}{l}\text { Loss of adhesion and invasion } \\
\text { activities, and decrease } \\
\text { of MMP-9 }\end{array}$ & NA & Growth inhibition & [92] \\
\hline $\begin{array}{l}\text { Fx and } \mathrm{FxOH} \\
(\sim 20 \mu \mathrm{M})\end{array}$ & $\begin{array}{l}\text { Primary cells in } \\
\text { CRC patients }\end{array}$ & & NA & Growth inhibition & [93] \\
\hline $\begin{array}{c}\text { FxOH }(\sim 5.0 \mu \mathrm{M} \\
\text { in vitro, } 5 \mathrm{mg} / \mathrm{kg} \\
\text { body weight in vivo })\end{array}$ & $\begin{array}{l}\text { HT-29 } \\
\text { (Csps) }\end{array}$ & $\begin{array}{c}\text { Decreases of } \\
\left.\text { phospho-AKT(Ser }{ }^{473}\right), \\
\text { PPAR } \beta / \delta \text { and PPAR } \gamma, \\
\text { suppression of tumorigenesis in } \\
\text { NOD/SCID mice }\end{array}$ & NA & Apoptosis & [97] \\
\hline
\end{tabular}


Table 2. Cont.

\begin{tabular}{|c|c|c|c|c|c|}
\hline $\begin{array}{l}\text { Brown Algal Extract } \\
\text { or Compound } \\
\text { (Additive } \\
\text { Concentration) }\end{array}$ & $\begin{array}{l}\text { Cell Line } \\
\text { (Cell Type) }\end{array}$ & $\begin{array}{l}\text { Promoted Molecular } \\
\text { Mechanism(s) }\end{array}$ & $\begin{array}{c}\text { Involved } \\
\text { Intracellular } \\
\text { Component }\end{array}$ & $\begin{array}{l}\text { Final Outcome } \\
\text { (Cell Function) }\end{array}$ & Reference \\
\hline $\mathrm{FxOH}(\sim 50 \mu \mathrm{M})$ & $\begin{array}{l}\text { HT-29 } \\
\text { (Csps) }\end{array}$ & $\begin{array}{l}\text { Suppressions of cell migration } \\
\text { and invasion; attenuations of } \\
\text { EMT, integrin, MAPK and STAT } \\
\text { signal proteins; decrease of p53; } \\
\text { and increase of active } \\
\text { caspase- } 3 \text { form }\end{array}$ & NA & $\begin{array}{c}\text { Apoptosis under } \\
\text { normoxia condition }\end{array}$ & [98] \\
\hline $\mathrm{FxOH}(\sim 50 \mu \mathrm{M})$ & $\begin{array}{l}\text { HT-29 } \\
\text { (Csps) }\end{array}$ & $\begin{array}{l}\text { Attenuations of EMT, integrin, } \\
\text { MAPK and STAT signal } \\
\text { proteins; decreases of HIF- } 1 \alpha \text {, } \\
\text { cyclin D1and p53; and increases } \\
\text { of phospho- } \beta- \\
\text { catenin }\left(\text { Ser }^{31 / 37} / \mathrm{Thr}^{42}\right) \text { and } \\
\text { active caspase- } 3 \text { form }\end{array}$ & NA & $\begin{array}{l}\text { Apoptosis under } \\
\text { hypoxia condition }\end{array}$ & [99] \\
\hline
\end{tabular}

Parent cells (PCs) indicate each intact cell line, most of which are the adherent types. Colonospheres (Csps) indicate a spheroid prepared from the parent cells by stem cell medium and some growth factors. Fx, fucoxanthin; FxOH, fucoxanthinol; NA, not available; PERK, protein kinase RNA (PKR)-like ER kinase; IRE1, inositol-requiring enzyme 1; ATF6, activating transcription factor 6; PARP, poly(ADPribose) polymerase; JNK, c-Jun NH2-terminal kinase; ERK, mitogen-activated protein kinase 1; PI3K/AKT, phosphatidylino-sitol-3 kinase/protein kinase B; MAPK, mitogen-activated protein kinase; NRF2, nuclear factor erythroid 2 [NF-E2]-related factor 2; TGF- $\beta$, transforming growth factor beta; STAT, signal transducers and activators of transcription; WNT, wingless/integrated; MEK, mitogenactivated protein/extracellular signal-regulated kinase; PPAR $\gamma$, peroxisome proliferator activated receptor gamma; CLIC4, chloride intracellular channel 4; NHERF2, $\mathrm{Na}^{+} / \mathrm{H}^{+}$exchanger regulatory factor 2; FAK, focal adhesion kinase; NF- $\mathrm{KB}$, nuclear factor- $\mathrm{kB}$; XIAP, X-linked inhibitor of apoptosis protein; cIAP-1, cellular inhibitor of apoptosis protein-1; MMP-9, matrix metallopeptidase 9; PPAR $\beta / \delta$, peroxisome proliferator activated receptor beta/delta; NOD/SCID, NOD.CB17-Prkdc scid /J; EMT, epithelial-mesenchymal transition; HIF- $1 \alpha$, hypoxia-inducible factor- 1 alpha.

Clinical data on humans are the most important to support both the experimental findings and the hypothesized relationship between Fx and CRC. However, it is necessary to accumulate evidence on the anticancer effect of Fx for CRC in both in vivo and in vitro experiments as the basic mechanism for discussing the implications on potential effect of Fx in human.

\section{Cancer Preventive Effect of Brown Algae and Fx in CRC Model Animals \\ 4.1. Cancer Chemopreventive Effect of Whole Brown Algae and Fx-Containing Extract}

Some researchers have reported on the anticancer properties of whole brown algae and Fx-containing extracts in CRC model animals.

Recently, we cultivated U. pinnatifida on the Nesaki coast of Hokkaido, Japan, for 3 months and collected algae with the highest Fx content in February 2017 (Fx-high wakame, $>5.0 \mathrm{mg} \mathrm{Fx} / \mathrm{g} \mathrm{dw}$ ). Using a CRC murine model (azoxymethane-dextran sodium sulfate [AOM/DSS] mice with an ICR background), we investigated the effects of whole Fx-high wakame feeding on colorectal TME. The administration of Fx-high wakame (equivalent to Fx $30 \mathrm{mg} / \mathrm{kg} \mathrm{bw}$ ) for 7 weeks significantly decreased the number of CCSCs-like CD44 $4^{\text {high }} /$ EpCAM $^{\text {high }}$ cells, CAFs-like $\alpha \mathrm{SMA}^{\text {high }}$ cells, TAMs- and DCs-like CD206 ${ }^{\text {high }}$ cells and increased apoptotic-cells-like cleaved caspase- $3^{\text {high }}$ cells in colorectal mucosal tissue in the mice. In addition, the salivary glycine level was found to be a predictor correlated with the chemopreventive efficacy of Fx-high wakame in the mice [51]. Kong et al. showed that the administration of Fx-rich extract (1-5 g extract $/ \mathrm{kg} \mathrm{bw}$ ) from S. muticum exerted antioxidation, anti-inflammation and/or anticancer effects in DSS-derived colitis-induced and AOM/DSS-induced BALB/c mice by reducing the disease activity score, nitric oxide (NO), malondialdehyde, TNF- $\alpha$ and IL- 6 and increasing the level of SOD. In addition, the extract prevented the onset of colorectal tumors and restored lymphocyte proliferation and survival rates [101]. Son et al. revealed that diet feeding both $2 \%$ and $6 \%$ whole $H$. fusiforme for 8 weeks significantly reduced the number of aberrant crypt foci (ACF) and the rate of proliferating cell nuclear antigen labeling index in mucosal tissue of an AOM-induced F344 rat CRC model [102]. Mahmoud et al. investigated the CRC chemopreventive effect 
using ethanol extracts of two brown algae, T. ornata and Padina pavonia, collected from the shore of the Red Sea in Egypt. The administration of $100 \mathrm{mg} / \mathrm{kg}$ bw of either T. ornata or P. pavonia extract for 8 weeks in colorectal tissue of AOM-induced albino Swiss CRC mice significantly prevented colorectal inflammation and oxidation by reducing the lipid peroxidation and NO levels and downregulating the NF- $\mathrm{BB}$ expression and upregulating the peroxisome proliferator-activated receptor gamma (PPAR $\gamma$ ) and p53 expression. In addition, the colorectal levels of GSH, SOD and GPx activities in the mice were significantly increased by the feeding of both T. ornata and P. pavonia extracts [82].

Of note, Das et al. prepared ethanol extract containing $15 \mathrm{mg}$ Fx/g from S. japonica and administered it as an ad libitum dimethyl sulfoxide solution (final Fx concentration: $0.075 \mathrm{mg} / \mathrm{mL}$ ) to AOM-initiated ddY mice for 4 weeks to investigate the difference in CRC chemoprevention from other groups given 0.05 and $0.1 \mathrm{mg} \mathrm{Fx} / \mathrm{mL}$ solutions. Consequently, the administrations of $S$. japonica extract, 0.05 and $0.1 \mathrm{mg} F x / \mathrm{mL}$ solutions all significantly decreased the number of colorectal ACF in the mice to similar degrees. These findings suggested that $S$. japonica extract exerted an inhibitory effect on the onset of colorectal ACF with the same potency as Fx alone [103]. Further complicating matters, Reddy et al. showed that the dietary intake of Laminaria angustata (Mitsuishikombu) (diet containing $10 \%$ algae) for 28 weeks significantly increased the incidence and multiplicity of colorectal tumors in an AOM-induced F344 rat CRC model [104].

\subsection{Cancer Chemopreventive Effect of Fucoxanthin Itself}

Some researchers have studied the direct anticancer property of Fx in CRC model animals. Our group previously found a cell death mechanism by which FxOH treatment induced anoikis in human CRC cells [86]. Anoikis is an apoptotic mechanism that occurs following cell detachment due to a lack of integrin anchor points between the cell and the extracellular matrix (ECM) or the cell and neighbor cells, and it is physiologically significant for tissue homeostasis and disease. During the anoikis process, certain core mechanisms, such as phosphatidylinositol-3 kinase/protein kinase B (PI3K/AKT), MAPK and transforming growth factor-beta (TGF- $\beta$ ) signals, are first inhibited by changes in some transmembrane receptors, and cells subsequently become detached from the ECM, finally inducing caspase activation, which triggers anoikis. Cancer cells frequently suppress this stepwise anoikis induction. Therefore, anoikis resistance in cancer cells is indispensable for the cell survival, epithelial-mesenchymal transition (EMT), invasion and metastasis [105-107].

Following our anoikis findings in vitro, we explored whether or not Fx administration in an AOM/DSS-induced ICR mouse model of CRC induced anoikis in the colorectal tissue. As a result, oral Fx administration $(30 \mathrm{mg} / \mathrm{kg}$ bw) for 2 weeks before sacrifice significantly suppressed the number and size of colorectal tumors by enhancing anoikislike integrin $\beta 1^{\text {low/- }}$, phospho(p)-FAK $\left(\mathrm{Tyr}^{397}\right)^{\text {low/- }}$ and pPaxillin $\left(\mathrm{Tyr}^{31}\right)^{\text {low/- }}$ with cleaved caspase- $3^{\text {high }}$ cells in the colorectal mucosal crypts [108]. Furthermore, Fx treatment also markedly increased the number of anoikis-like integrin $\beta 1^{\text {low/- }} /$ cleaved caspase- $3^{\text {high }}$ cells in colorectal adenocarcinoma in the mice [109]. These two reports suggest that the induction of anoikis by Fx was the relevant anticancer mechanism in AOM/DSS mice. CCSCs often promote an EMT accompanied by the alterations of related proteins. EMT is considered to mediate their migration and invasion of the cells and to cause CRC recurrence and distant metastasis [110]. Therefore, the inhibition of the EMT phenotype in CCSCs would be a promising approach for cancer prevention. We speculate that the anoikis induction in colorectal normal mucosa and adenocarcinoma of AOM/DSS mice with Fx treatment lead to suppress the occurrence and EMT activation of CCSCs.

The formation of TME is a significant process in the onset of adenocarcinoma in colorectal mucosal tissue [20-22]. We previously showed that Fx administration (30 mg/kg bw) for 8 and 14 weeks significantly prevented colorectal carcinogenesis and decreased the number of CCSCs-like CD44 ${ }^{\text {high }} /$ EpCAM $^{\text {high }}$ cells, CAFs-like $\alpha$ SMA ${ }^{\text {high }}$ cells, TAMsand DCs-like CD206 $6^{\text {high }}$ cells and/or increased apoptotic cell-like cleaved caspase- $3^{\text {high }}$ 
cells in colorectal mucosal tissue in AOM/DSS mice. In addition, the salivary glycine level was found to be a predictor of the chemopreventive efficacy of Fx in the mice [111,112]. These findings suggested that $\mathrm{Fx}$ was a promising inducer for the occurrence suppression in CCSCs of the mice.

Notably, changes in the gut microbiota can also function as a key trigger in human colorectal carcinogenesis $[15,113,114]$. We investigated the chemopreventive potency of Fx and its effect on the gut microbiota in AOM/DSS mice. Oral Fx administration (30 mg/kg $\mathrm{bw}$ ) for 14 weeks significantly prevented the onset of colorectal adenocarcinoma in mice with attenuations of Bacteroidlales and Rikenellaceae and enhancement of Lachnospiraceae in the fecal microbiota composition. Of note, the oral administration of a fecal suspension from the Fx-treated mouse suppressed the number of colorectal adenocarcinoma in another AOM/DSS mice with a successful increase of gut Lachnospiraceae. These findings suggested that the induction of changes in the gut microbiota by Fx is a significant mechanism underlying the cancer chemopreventive effects of Fx in AOMDSS mice [115].

CCSCs occupy only a small subset of CRC tissue, but they are thought to play an important role in cancer progression. Self-renewal, sphere formation, differentiation, and tumorigenicity in animals have been characterized as biological properties for CCSCs [94,95]. Therefore, we especially focused on the effects of $\mathrm{Fx}$ and $\mathrm{FxOH}$ on the tumorigenesis from CCSCs in two immunodeficiency murine models. Consequently, we have revealed that the administration of Fx and FxOH inhibited tumorigenesis in xenograft NOD/SCID and BALB/c mice, respectively, subcutaneously injected with CCSCs-like cells prepared from human CRC HT-29 cells. In addition, the administration of Fx to BALB/c mice significantly downregulated the cyclin D1 expression in the tumor $[97,116]$. Furthermore, we investigated the effect of Fx in a $A p c^{\text {Min/+ }}$ mouse model of human FAP. The intake of Fx diet $(1000 \mathrm{ppm})$ for 5 weeks significantly attenuated the number of colorectal adenocarcinoma lesions in DSS-treated $A p c^{\mathrm{Min} /+}$ mice with downregulation of cyclin D1 expression in mucosal tissues [117]. One group described the effects of Fx in another animal model: Kim et al. showed that Fx administration in drinking water (0.01\%) for 7 weeks significantly suppressed the onset of colorectal ACF and the BrdU Labeling Index in the colorectal crypt compartment in a 1,2-dimethylhydrazine-induced murine $\mathrm{CRC}$ model $\left(\mathrm{B}_{6} \mathrm{C} 3 \mathrm{~F}_{1}\right)$ [41].

Many reports have described the cancer chemopreventive effects seen in animal CRC models treated with whole brown algae, extract containing Fx and Fx itself. However, the detailed molecular mechanisms underlying these effects in the colorectal tissue of animal models remain elusive. Further investigations are needed to determine the CRC chemopreventive effects of brown algae and Fx.

\subsection{Effect by Brown Algae and Fx in CRC Risks}

Many researchers have reported the attenuation of CRC risk factors, such as antiobesity, anti-metabolic syndrome and anti-inflammation effects, and changes in gut microbiota by whole brown algae, Fx-containing extracts and Fx itself in animal models. Diets containing $U$. pinnatifida ethanol extracts, equivalent to $0.05 \%$ and $0.2 \% \mathrm{Fx}$, which has already demonstrated anti-obesity effects when administered through the diet in C57BL/6N mice, or another diet containing S. horneri powders $(2 \%$ and $6 \%)$ reduced both the body and WAT weights in C57BL/6J mice fed a high-fat diet, with enhancement of the UCP-1 mRNA expression in WAT [118-120]. Okada et al. also reported on the anti-obesity effects, characterized by reductions in the body and WAT weights, changes in serum lipid profiles and upregulation of the UCP-1 protein and mRNA expression in KK- $\mathrm{A}^{\mathrm{y}}$ mice with $U$. pinnatifida lipid treatment $(0.2 \%$ as a drink; $1.0 \%$ as a diet) [73]. Grasa-López et al. revealed the anti-obesity and anti-inflammation effects of both $U$. pinnatifida $(400 \mathrm{mg} / \mathrm{kg}$ $\mathrm{bw})$ and $\mathrm{Fx}(1 \mathrm{mg} / \mathrm{kg} \mathrm{bw})$ in Wister rats given a high-fat diet, along with the upregulation of PPAR $\alpha$, PPAR $\gamma$ coactivator- $1 \alpha$, PPAR $\gamma$ and UCP-1 and downregulation of IL-6 [34]. Diet containing S. polycystum (2.5-10.0\%) induced significant decreases in the BW and plasma LDL-cholesterol and TAG levels and increased the high-density lipoprotein-cholesterol levels in Sprague-Dawley rats fed a high-fat diet [121]. The oral administration of extracts 
from two brown algae-P. pavonia and T. ornata $(100 \mathrm{mg} / \mathrm{kg} \mathrm{bw})$-for $21 \mathrm{~d}$ exerted antioxidation and anti-inflammation effects in streptozotocin/nicotinamide-induced type 2 diabetic rats (albino) through the reductions in glucose, TNF- $\alpha$ and malondialdehyde, and increases of insulin, GSH, GPx and SOD [122]. An ethanol extract of the brown algae Petalonia binhamiae ( $150 \mathrm{mg} / \mathrm{kg} \mathrm{bw}$ ) for $70 \mathrm{~d}$ induced an anti-obesity effect with many obesity-related markers in high-fat-diet-fed C57BL/6 mice [123]. Maeda et al. showed that the administration of diets containing Fx-rich $U$. pinnatifida extract $(2.0 \%)$ significantly reduced the WAT weight in both Wister rats and KK- $\mathrm{A}^{\mathrm{y}}$ mice, but not the BAT weight. In addition, both a $2.0 \% \mathrm{U}$. pinnatifida-containing diet and $0.4 \% \mathrm{Fx}$ diet induced the marked upregulation of the UCP1 expression in WAT of KK-A $\mathrm{A}^{\mathrm{y}}$ mice compared with that in control mice [124]. Similarly, those authors further demonstrated the anti-obesity and anti-diabetic effects of Fx in KK-A $\mathrm{A}^{\mathrm{y}}$ and C57BL/6J mice [125-130]. Other researchers have described the anti-diabetic effect of $\mathrm{Fx}$ and $U$. pinnatifida extract in C57BL/6N and C57BL/6J mice, respectively $[131,132]$. Furthermore, treatment with Fx $(50$ and $100 \mathrm{mg} / \mathrm{kg})$ could exert the anti-inflammatory effect with BW reduction and colorectal mucosal damage, decreases of PGE2, COX-2 and NF- $\kappa$ B in a DSS-induced colitis murine model [133]. Another group reported on changes in the gut microbiota in the administration of whole brown algae. The intake of a diet containing $10 \%$ dried $U$. pinnatifida or S. japonica for 4 weeks increased the Prevotella, Alistipes and Bacteroides genera and decreased the Roseburia, Mollicute and Oscillibacter genera in feces of Sprague-Dawley rats [134]. Another two groups explored the alteration of the gut microbiota in obese mice by Fx. Sun et al. showed that the administration of a high-fat diet containing Fx (1 mg Fx/g diet) decreased the rate of Lachnospiraceae and Erysipelotrichaceae and increased the rates of Lactobacillus, Lactococcus, Bifidobacterium and several butyrate-producing bacteria in feces of an obese murine C57BL/6J model, along with decreasing serum levels of TNF- $\alpha$ and IL-6. In addition, the gut bacterial taxa were significantly associated with obesity phenotypes and the degree of inflammation [135]. Another group reported that Fx administration $(125 \mathrm{mg} / \mathrm{kg} \mathrm{bw})$ for 4 weeks reduced BW and changed the cecal and fecal microbiota in BALB/c mice given a normal or a high-fat diet. In particular, changes in the ratio of Firmicutes/Bacteroidetes and the composition of S24-7 and Akkermansia were observed in the cecal contents [136]. Furthermore, Liu et al. prepared a fecal bacterial suspension from C57BL/6 mice served a normal diet. The bacteria were cultured under anaerobic conditions and treated with $0.1 \mathrm{mg} / \mathrm{mL}$ Fx. The Fx treatment consequently suppressed the growth of Escherichia coli but promoted that of Lactobacilli [137]. Figure 2 summarizes the molecular mechanisms underlying the effects of whole brown algae, Fx-rich extract and Fx on CRC itself or its risk factors in animal models.

Whole brown algae, the Fx-rich extract, $\mathrm{Fx}$ and $\mathrm{FxOH}$
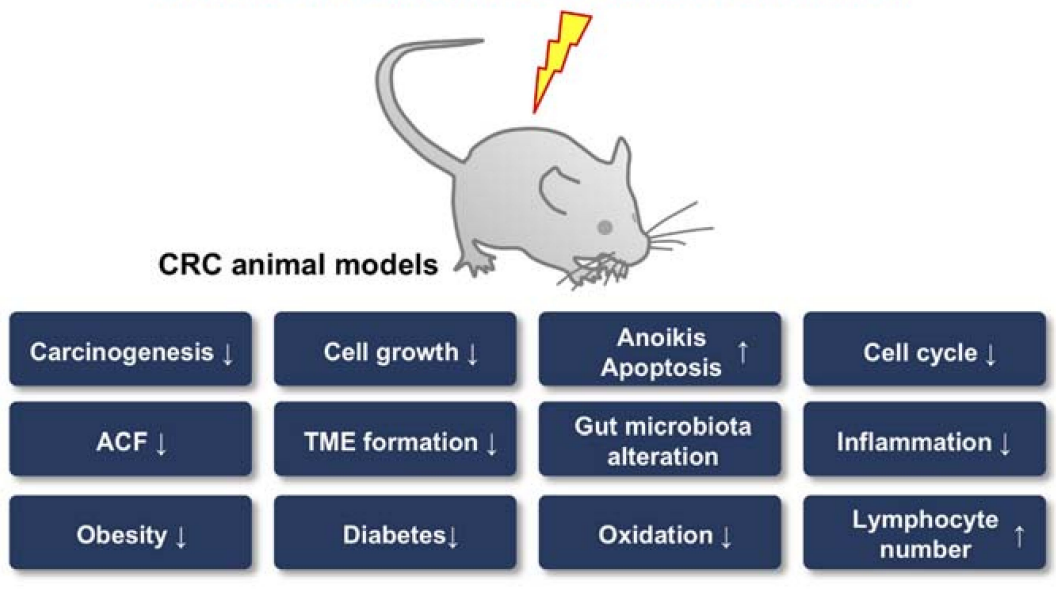

Figure 2. Possible mechanisms underlying the cancer chemopreventive effects of whole brown algae, fucoxanthin (Fx)-rich extract, Fx and fucoxanthinol (FxOH) against colorectal cancer (CRC). ACF, aberrant crypt foci; TME, tumor microenvironment. $\uparrow$, induction or increase; $\downarrow$, inhibition or decrease. 


\section{Beneficial Effects of Brown Algae and Fx in Human}

\subsection{Effects of Fx and Fx-Containing Materials on the Risk Factors Associated with CRC}

Little information is available on the direct mechanisms underlying the anti-CRC properties of Fx and Fx-containing materials. However, interventional studies have shown that whole brown algae, Fx extracts and Fx itself can improve the risk factors associated with CRC, such as obesity, diabetes, metabolic syndrome, inflammation and oxidation.

Obesity is a chronic metabolic disorder defined as excessive visceral fat accumulation, typically characterized by a body mass index (BMI) of $\geq 30 \mathrm{~kg} / \mathrm{m}^{2}$ ( $\geq 25 \mathrm{~kg} / \mathrm{m}^{2}$ in Japan), an increased waist circumference and/or a reduced energy expenditure [138]. Large cohort studies have described a positive association between obesity and CRC $[139,140]$ and between diabetes and CRC $[141,142]$. Obesity is mainly caused by overeating, low physical activity and heritable features. The disease leads to low-level inflammation and metabolic syndrome, such as hyperlipidemia, hypertension, diabetes mellitus, nonalcoholic fatty liver disease (NAFLD) and arteriosclerosis. The excessive fat accumulation is accompanied by invasion of inflammatory cells into adipose tissue, which secretes cancerrelated adipokines/chemokines including adiponectin, plasminogen activator inhibitor-1 (PAI-1), leptin, resistin, tumor necrosis factor- $\alpha$ (TNF- $\alpha)$, monocyte chemoattractant protein1 (MCP-1), nicotinamide phosphoribosyltransferase (NAMPT), interleukine-6 (IL-6) and lipocalin 2 [143-147].

Inflammation is a protective response that causes injured tissues to heal. However, chronic inflammation induced by the persistent activation of signaling pathways without normal healing is a major CRC risk factor [148-150]. The core inflammatory mediators in white blood cells and tissue cells, such as nuclear factor- $\mathrm{kB}$ (NF- $\mathrm{kB}$ ), cyclooxygenase-2 (COX-2), prostaglandin E2 (PGE2), peroxisome proliferator-activated receptor $\delta$ (PPAR $\delta$ ), IL-6, mitogen-activated protein kinase (MAPK), c-Jun $\mathrm{NH}_{2}$-terminal kinases and activating protein-1, lead to carcinogenesis; therefore, the suppression of these inflammatory activators is a significant target for anti-inflammatory agents [151-153].

Oxidative stress resulting from increased production of reactive oxygen species (ROS) by various stimuli is also strongly associated with the development of CRC and IBD [154-160]. Enhanced oxidative stress induces increased DNA base oxidation (8OHdG8hydroxy-2'-deoxyguanosine) and lipid peroxidation under conditions of inflammation and carcinogenesis in human subjects $[161,162]$. The ROS superoxide $\left(\mathrm{O}_{2}{ }^{-}\right)$, hydroxyl radicals $\left(\mathrm{HO}^{\prime}\right)$ and hydrogen peroxide $\left(\mathrm{H}_{2} \mathrm{O}_{2}\right)$ are mainly generated through the mitochondrial electron transport chain via enzymatic and non-enzymatic pathways, and their byproducts are balanced by glutathione (GSH) and antioxidant enzymes, such as superoxide dismutase (SOD), catalase, glutathione peroxidase (GPx), peroxiredoxin or antioxidant agents, to achieve a normal cell function [163]. However, excessive ROS generation frequently plays a major role in tumorigenesis [164,165].

As an early experiment, Adidov et al. investigated the anti-obesity effect of the Fx-containing oil Xanthigen ${ }^{\mathrm{TM}}$ (PL Thomas \& Co., Morristown, NJ, USA) in humans. The consumption of Xanthigen-600, which is composed of an algal extract (equivalent to $2.4 \mathrm{mg}$ Fx) and plant oil, by obese premenopausal women with NAFLD or normal liver fat content for 16 weeks significantly decreased their BW, waist circumference, body and liver fat content, liver enzymes, serum TAG and/or C-reactive protein levels [166]. Mikami et al. prepared 1 and $2 \mathrm{mg}$ Fx capsules composed of an algal oil extracted from S. horneri, medium-chain triacylglycerol, lecithin and vitamin E. The administration of $2 \mathrm{mg} \mathrm{Fx} / \mathrm{d}$ for 8 weeks significantly decreased the HbA1c level compared with the placebo control. They investigated the polymorphism status of uncoupling protein 1 (UCP1) in the subjects [33]. UCP1, a mitochondrial membrane protein, plays a central role in the metabolic thermogenesis process for inhibiting excessive fat accumulation [167]. The UCP1 molecule is strongly expressed in brown adipose tissue (BAT), which promotes whole body energy expenditure, and its protein aberration leads to the development of obesity, although most fat is accumulated in the white adipose tissue (WAT), where UCP1 is absent. Of note, UCP-1 can be induced by various intrinsic and extrinsic stimuli [168-170]. Maeda et al. 
demonstrated that the intake of a diet containing Fx-rich U. pinnatifida extract significantly reduced the WAT weight with the enhancement of UCP1 expression in KK-A mice [124]. Interestingly, the reduction of $\mathrm{HbA1c}$ in subjects with the UCP1-3826 G/G genotype was significantly greater than that in those with an A/A or A/G genotype. No significant change in the $\mathrm{HbA} 1 \mathrm{c}$ level was observed following $1 \mathrm{mg} \mathrm{Fx}$ administration [33]. A capsule of phlorotannin $(107.3 \mathrm{mg})$ and $\mathrm{Fx}(36.5 \mathrm{mg})$-rich content was prepared from ethanol extract of $A$. nodosum collected on the coast of the United Kingdom and administered to individuals with a BMI $\geq 25$ for 8 weeks. As a result, the algal extract slightly reduced the DNA damage in these obese individuals [171].

However, some researchers have described the beneficial effects for humans of whole brown algae or its extract with unknown Fx contents. The intake of $0.9 \mathrm{~g} \mathrm{~A}$. nodosum for 6 weeks reduced the BW, BMI and TAG level and enhanced the adiponectin levels in healthy volunteers [172]. A single dose of both $U$. pinnatifida itself $(4 \mathrm{~g})$ and its sporophylls (70 g) significantly decreased the postprandial glucose concentration in plasma of healthy volunteers at $0.5 \mathrm{~h}$ after a meal $[173,174]$. Dosage plan of $4 \mathrm{~g} / \mathrm{d}$ for 4 weeks plus $6 \mathrm{~g} / \mathrm{d}$ for 4 weeks of $U$. pinnatifida powder-packed capsules brought about reductions in the systolic blood pressure and waist circumference in participants with at least one symptom of metabolic syndrome [175]. A daily intake of $50 \mathrm{~g}$ of a snack food containing $64 \mathrm{mg}$ of whole U. pinnatifida for 8 weeks significantly reduced the total cholesterol, low density lipoprotein (LDL)-cholesterol and resistin levels [176]. The administration of fermented S. japonica $(1.5 \mathrm{~g} / \mathrm{d})$ for 4 weeks significantly downregulated the activities of catalase and SOD [177]. The intake of $S$. japonica (6 g/d for 4 weeks) also improved the molecular species profiles of phosphatidylcholine (PC), phosphatidylethanolamine (PE), lysophosphatidylcholine and lysophosphatidylethanolamine as well as the free fatty acid levels, and algal ingestion increased the plasmanyl and plasmenyl forms of PC and PE in the serum of participants with abnormal serum triacylglycerol levels $[178,179]$. Furthermore, dietary intervention of $S$. japonica ( $2 \mathrm{~g} / \mathrm{d}$ for 6 weeks) reduced the body fat proportion and enhanced the adiponectin level in healthy volunteers [180].

Brown algae contain many attractive hydrophilic and lipophilic compounds with nutritional benefits for both humans and animals. The promising agents considered to be involved in these effects include Fx, fucosterol, polyunsaturated fatty acids, polysaccharides, peptides, bromophenols, phlorotannins and assorted minerals [181-183]. Therefore, it must be noted that the beneficial effects of whole brown algae and its extract in human subjects are not due to Fx alone.

\subsection{Effects of Fucoxanthin Itself on CRC Risk}

Abidov et al. have demonstrated that administration of 2.4-8.0 mg Fx for 16 weeks enhanced the resting energy expenditure in obese volunteers with NAFLD but had no effect at $1.6 \mathrm{mg}$ [166]. Hitoe et al. investigated the anti-obesity effect of the commercial Fx oil Fucoxanthin-P1 containing a powder with 1\% Fx (Oryza Oil \& Fat Chemical Co. Ltd., Osaka, Japan) in Japanese adults with a BMI $\geq 25 \mathrm{~kg} / \mathrm{m}^{2}$. Consequently, the interventional intake of $3 \mathrm{mg} \mathrm{Fx} / \mathrm{d}$ for 4 weeks significantly reduced the BMI, fat areas (total, subcutaneous and visceral parts) and waist circumference compared with placebo groups. In addition, the administration of $1 \mathrm{mg} \mathrm{Fx} / \mathrm{d}$ for 4 weeks decreased the total fat area alone [32].

In summary, interventional studies, a prospective cohort study and two case-control studies on the association between the intake of seaweed likely containing brown algae and CRC have shown promising findings concerning the effect of brown algae intake on preventing CRC. In addition, the daily intake of $>0.9 \mathrm{~g}$ of whole brown algae or $2 \mathrm{mg}$ of $\mathrm{Fx}$ may result in anti-obesity, anti-metabolic syndrome, antioxidation and anti-inflammation effects. To date, there is little information available concerning interventional studies of brown algae and Fx for gut microbiota and hereditary CRC syndromes. Further work is needed to confirm the response in patients with CRC or CRC risks.

The interventional results concerning whole brown algae, Fx-rich extracts and purified Fx are summarized in Table 3. 
Table 3. Effect of brown algae and fucoxanthin on CRC risk factors in human interventional studies.

\begin{tabular}{|c|c|c|c|c|c|}
\hline Brown Algae Source & Fx Dosage & Administration Type & Study Design & Effect & Reference \\
\hline Unknown & $2.4 \mathrm{mg} / \mathrm{d}$ & $\begin{array}{l}\text { A capsule of algal lipid-rich } \\
\text { extract containing } 300 \mathrm{mg} \\
\text { pomegranate seed oil and } \\
300 \mathrm{mg} \mathrm{dw} \text { brown algal } \\
\left.\text { extract (Xanthigen }{ }^{\mathrm{TM}}\right)\end{array}$ & $\begin{array}{l}\text { Double-blind, } \\
\text { placebo-controlled, } \\
\text { randomized trial in } \\
151 \text { women with } \\
\text { non-diabetic and obese } \\
\text { premenopausal (period, } \\
16 \text { weeks) }\end{array}$ & $\begin{array}{l}\text { Reductions of BW, waist } \\
\text { circumference, body and } \\
\text { liver fat contents, liver } \\
\text { enzymes, serum TAG and } \\
\text { C-reactive protein }\end{array}$ & {$[166]$} \\
\hline Sargassum horneri & $2.0 \mathrm{mg} / \mathrm{d}$ & $\begin{array}{l}\text { A capsule containing } \\
220 \mathrm{mg} \mathrm{dw} \text { S. horneri } \\
\text { Fx-rich extract }\end{array}$ & $\begin{array}{l}\text { Single-blind, } \\
\text { placebo-controlled, } \\
\text { randomized trial in } \\
60 \text { adults ( } 30-77 \text { y) with } \\
\text { normal-weight and obese } \\
\text { (period, } 8 \text { weeks) }\end{array}$ & $\begin{array}{l}\text { Reductions of blood } \\
\text { HbA1c level }\end{array}$ & [33] \\
\hline Ascophyllum nodosum & $36.5 \mathrm{mg} / \mathrm{d}$ & $\begin{array}{l}\text { A capsule containing } 100 \\
\text { mg dw A. nodosum } \\
\text { ethanol/water extract }\end{array}$ & $\begin{array}{c}\text { Double-blind, } \\
\text { placebo-controlled, } \\
\text { randomized trial in } 80 \\
\text { women (30-65 y) with } \\
\text { obese (period, } 8 \text { weeks) }\end{array}$ & $\begin{array}{l}\text { Weak inhibition of } \\
\text { DNA damage }\end{array}$ & {$[171]$} \\
\hline Ascophyllum nodosum & Unknown/d & $\begin{array}{l}\text { A capsule containing } \\
900 \mathrm{mg} \mathrm{dw} \text { of whole } \\
\text { A. nodosum }\end{array}$ & $\begin{array}{c}\text { Double-blind, } \\
\text { placebo-controlled, } \\
\text { randomized trial in } \\
43 \text { healthy adults }(21-63 y) \\
\text { (period, } 6 \text { weeks) }\end{array}$ & $\begin{array}{c}\text { Reductions of BW, BMI, } \\
\text { TAG, and TNF- } \alpha \text { levels, } \\
\text { and increase } \\
\text { of adiponectin }\end{array}$ & {$[172]$} \\
\hline Undaria pinnatifida & Unknown & $\begin{array}{l}\text { Meat containing } 70 \mathrm{~g} \text { ww of } \\
\text { U. pinnatifida sporophyll }\end{array}$ & $\begin{array}{l}\text { Interventional study in } \\
12 \text { healthy adults (average } \\
25.4 y) \text { (period, } 180 \mathrm{~min})\end{array}$ & $\begin{array}{l}\text { Reductions of plasma } \\
\text { glucose and its AUC }\end{array}$ & {$[173]$} \\
\hline Undaria pinnatifida & Unknown & $\begin{array}{l}4 \mathrm{~g} \mathrm{dw} \text { of } U \text {. pinnatifida } \\
\text { (FUERU } \\
\text { WAKAME-CHAN }{ }^{\circledR} \text { ) } \\
\text { with rice }\end{array}$ & $\begin{array}{l}\text { An open-label, two-period, } \\
\text { placebo-controlled, } \\
\text { randomized trial in } \\
26 \text { healthy adults (average } \\
51.5 \text { y) (period, } 120 \text { min) }\end{array}$ & $\begin{array}{l}\text { Reductions of blood } \\
\text { glucose and insulin } \\
\text { levels, and those AUC }\end{array}$ & {$[174]$} \\
\hline Undaria pinnatifida & Unknown/d & $\begin{array}{l}\text { A capsule containing } 4 \mathrm{~g} \\
\text { dw of } U \text {. pinnatifida } \\
\text { sporophyll/d for } 4 \text { weeks } \\
\text { plus } 6 \mathrm{~g} \text { the alga/d for } \\
4 \text { weeks }\end{array}$ & $\begin{array}{c}\text { Double-blind, } \\
\text { placebo-controlled, } \\
\text { randomized trial in } \\
27 \text { adults (average } 46.2 \mathrm{y} \text { ) } \\
\text { with at least one symptom } \\
\text { of the metabolic syndrome } \\
\text { (period, } 8 \text { weeks) }\end{array}$ & $\begin{array}{l}\text { Reductions of systolic } \\
\text { blood pressure and } \\
\text { waist circumference }\end{array}$ & {$[175]$} \\
\hline Undaria pinnatifida & Unknown/d & $\begin{array}{c}\text { A snack containing } 32 \mathrm{mg} \\
\mathrm{dw} \text { of } U \text {. pinnatifida }\end{array}$ & $\begin{array}{c}\text { Double-blind, } \\
\text { placebo-controlled, } \\
\text { randomized trial in } 32 \\
\text { adults (average 51.1 y) with } \\
\text { obese (period, } 8 \text { weeks) }\end{array}$ & $\begin{array}{l}\text { Reductions of } \\
\text { LDL-cholesterol, } \\
\text { total-cholesterol and } \\
\text { resistin level }\end{array}$ & [176] \\
\hline Saccharina japonica & Unknown/d & $\begin{array}{c}1.5 \mathrm{~g} \mathrm{dw} \text { of fermented } S . \\
\text { japonica }\end{array}$ & $\begin{array}{l}\text { Double-blind, } \\
\text { placebo-controlled, } \\
\text { randomized trial in } \\
48 \text { healthy volunteers } \\
\text { (period, } 4 \text { weeks) }\end{array}$ & $\begin{array}{l}\text { Reductions of serum } \\
\gamma \text {-GT and MDA, } \\
\text { increases of SOD and } \\
\text { CAT activities }\end{array}$ & [177] \\
\hline Saccharina japonica & Unknown/d & $6 \mathrm{~g} \mathrm{dw}$ of roasted S. japonica & $\begin{array}{l}\text { Interventional study in } \\
52 \text { adults (39-86 y) with } \\
\text { normal and abnormal } \\
\text { serum TAG levels (period, } \\
4 \text { weeks) }\end{array}$ & $\begin{array}{l}\text { Reduction of serum TAG, } \\
\text { Improvements of } \\
\text { molecular species of PC, } \\
\text { PE, LPC, LPE and FFA in } \\
\text { the subjects with } \\
\text { abnormal serum } \\
\text { TAG level }\end{array}$ & {$[178,179]$} \\
\hline Saccharina japonica & Unknown/d & $\begin{array}{c}\text { A capsule containing } 2.0 \mathrm{~g} \\
\mathrm{dw} \text { of } S \text {. japonica }\end{array}$ & $\begin{array}{c}\text { Double-blind, } \\
\text { placebo-controlled, } \\
\text { randomized trial in } \\
70 \text { healthy adults (average } \\
56.6 \text { y) (period, } 6 \text { weeks) }\end{array}$ & $\begin{array}{l}\text { Reduction of body fat } \\
\text { and improvement of } \\
\text { adiponectin level }\end{array}$ & {$[180]$} \\
\hline
\end{tabular}


Table 3. Cont.

\begin{tabular}{|c|c|c|c|c|c|}
\hline Brown Algae Source & Fx Dosage & Administration Type & Study Design & Effect & Reference \\
\hline Unknown & $2.4-8.0 \mathrm{mg} / \mathrm{d}$ & $\begin{array}{c}\text { A capsule of } 100 \mathrm{mg} \text { algal } \\
\text { lipid-rich extract }\end{array}$ & $\begin{array}{l}\text { Double-blind, } \\
\text { placebo-controlled, } \\
\text { randomized trial in } \\
41 \text { women with } \\
\text { non-diabetic obese and } \\
\text { NAFLD (period, } 16 \text { weeks) }\end{array}$ & $\begin{array}{l}\text { Increase of resting } \\
\text { energy expenditure }\end{array}$ & [166] \\
\hline $\begin{array}{c}\text { Undaria pinnatifida } \\
\text { and Saccharina } \\
\text { japonica }\end{array}$ & $3.0 \mathrm{mg} / \mathrm{d}$ & $\begin{array}{l}\text { A capsule containing } \\
1.5 \mathrm{mg} \text { Fx powder } \\
\left(\text { Fucoxanthin-P1 }{ }^{\circledR}\right)\end{array}$ & $\begin{array}{c}\text { Double-blind, } \\
\text { placebo-controlled, } \\
\text { randomized trial in } \\
33 \text { adults (average } 42.8 \text { y) } \\
\text { with a BMI } \geq 25 \text { (period, } 4 \\
\text { weeks) }\end{array}$ & $\begin{array}{l}\text { Reductions of BMI, fat } \\
\text { area, waist circumference }\end{array}$ & [32] \\
\hline
\end{tabular}

Fx, fucoxanthin; Dw, dry weight; BW, body weight; TAG, triacylglycerol; HOMA, homeostatic model assessment; BMI, body mass index; AUC, Area under the curve; ww, wet weight; LDL, lipoprotein; $\gamma$-GT, $\gamma$-glutamyltransferase; MDA, malondialdehyde; SOD, superoxide dismutase; CAT, catalase; NAFLD, non-alcoholic fatty liver disease.

\subsection{Clinical Studies with Whole Brown Algae and Fx-Containing Extracts in CRC}

Hoshiyama et al. showed that a high intake of seaweed, likely including $U$. pinnatifida, showed a significant trend toward an inverse association with the risk of overall CRC (odds ratio $(\mathrm{OR}), 95 \%$ confidence interval $\left.(\mathrm{CI})=0.2[0.0-0.9], \mathrm{P}_{\text {trend }}<0.01\right)$ and rectal cancer $\left(\mathrm{OR}, 95 \% \mathrm{CI}=0.4\right.$ [0.1-1.1], $\left.\mathrm{P}_{\text {trend }}=0.01\right)$ as a case-control study in Japan [184]. In addition, Minami et al. investigated the association between the Japanese food intake and major digestive tract cancers from 1997 to 2013 as a prospective cohort study at an institution in Japan. As a result, the intake of seaweed, likely including $U$. pinnatifida, tended to be inversely associated with death in patients with rectal cancer $\left(P_{\text {trend }}=0.02\right)$ [185]. Kim et al. reported a significant inverse association between dietary intake of algae containing $U$. pinnatifida and CRC in a case-control study of Korean patients (OR, 95\% $\mathrm{CI}=0.65$ [0.50-0.85]). In addition, the rs6983267 polymorphism of c-MYC, an oncogene, was associated with a significant interaction between the dietary algae intake and both the overall CRC and rectal cancer risk [186]. Epidemiological data in humans supporting the role of Fx in CRC prevention are few and not well-addressed. They involve the same geographic area, Japan [184,185] and Korea [186]. Although there are no or few specific algae among those listed in Table 1, they contain Fx at different amounts. Indeed, the sample size is relatively small, but epidemiological studies $[185,186]$ may suggest that dietary seaweed containing Fx have a positive benefit as a chemoprevention and/or chemotherapeutic agent for CRC risk.

\section{Conclusions}

The high-polarity xanthophyll Fx is specific to brown algae, and microalgae and has been verified as safe without side effects in human $[24,32,166]$. This review discussed the most recent studies available concerning Fx as a potentially useful agent for CRC prevention.

Edible brown algae are often high in Fx content, and their consumption has been expanding in Asia, North and South America and Europe. In particular, the three algae, $U$. pinnatifida, S. horneri and H. elongata, are not only commonly eaten all around the world, but they have also been proven considerable Fx sources (Table 1). Brown algae are characterized by increased Fx production under low-sunlight conditions with cold seawater temperatures. Therefore, U. pinnatifida, S. horneri and H. elongata collected during the period of high Fx production may be useful as potent sources of Fx. In addition, the acquisition of Fx from not only brown algae but also microalgae can be convenient on large-scale preparation for food, cosmetic and pharmaceutical applications (Figure 1).

Fx-rich extract, $\mathrm{Fx}$ and $\mathrm{FxOH}$ can induce apoptosis and anoikis in human CRC cells and their spheroids through a number of molecular mechanisms. Such treatments can alter the activities and protein expression of caspases, Bax, Bcl-2, PARP, JNK, MAPK, PI3K/AKT, integrin, $\mathrm{WNT} / \beta$-catenin, STAT and PPARs and induce changes in the cell cycle, DNA 
damage and the CRC cellular functions of adhesion, migration and invasion, as well as the mitochondria and endoplasmic reticulum of these cells (Table 2). A few molecular alterations in human CRC cells were correspondingly observed in CRC animal models treated with whole brown algae, its Fx-rich extract or Fx itself. Consecutive studies in vitro will be important as the basis for clarifying the molecular mechanisms underlying cancer prevention in humans with CRC and CRC animal models by brown algae and Fx. Further studies are needed to confirm the anticancer mechanisms in both CRC animal models and cells.

CRC animal models have been the vehicle for many discoveries concerning the anticancer effects of whole brown algae, its Fx-rich extract and Fx itself. The TME, inflammation, oxidation and gut microbiota, which are significant factors associated with colorectal carcinogenesis, have been reported to be prime targets of Fx and were found to be altered by this agent's cancer chemopreventive properties. In addition, the administration of Fx induced anoikis in CRC animal models (Figure 2). However, the detailed molecular mechanisms underlying the cancer chemopreventive effect in animals remain poorly understood.

Few reports on the direct anticancer effects of Fx intake on human CRC have been published. However, the negative association between the intake of seaweed likely including brown algae and human CRC has been reported. IBD, heritable factors, obesity, diabetes, metabolic syndrome, inflammation and oxidation are suggested as key risks triggering colorectal carcinogenesis. Interventional approaches have revealed that the administration of whole brown algae, its Fx-rich extract and Fx itself can ameliorate most of these CRC risks (Table 3). However, the underlying mechanisms remain elusive. Further clinical investigations are needed to assess the anticancer effect of Fx in humans.

Finally, this review suggests that whole brown algae, its Fx-rich extract, Fx and FxOH may be potential candidates as beneficial agents for preventing CRC.

Author Contributions: Conceptualization, M.T.; writing-original draft preparation, M.T. and T.T.; writing-review and editing, A.K., H.K., H.M., K.M., C.K. and M.M. All authors have read and agreed to the published version of the manuscript.

Funding: This work was supported in part by the Japan Society for the Promotion of Science KAKENHI (nos. 16K07880 and 20K05879).

Conflicts of Interest: The authors declare no conflict of interest.

\section{References}

1. Ferlay, J.; Colombet, M.; Soerjomataram, I.; Mathers, C.; Parkin, D.M.; Piñeros, M.; Znaor, A.; Bray, F. Estimating the global cancer incidence and mortality in 2018: GLOBOCAN sources and methods. Int. J. Cancer 2019, 144, 1941-1953. [CrossRef] [PubMed]

2. Arnold, M.; Sierra, M.S.; Laversanne, M.; Soerjomataram, I.; Jemal, A.; Bray, F. Global patterns and trends in colorectal cancer incidence and mortality. Gut 2017, 66, 683-691. [CrossRef] [PubMed]

3. American Cancer Society. Colorectal Cancer Facts \& Figures 2020-2022. Available online: https:/ /www.cancer.org/research/ cancer-facts-statistics/colorectal-cancer-facts-figures.html (accessed on 20 February 2021).

4. Eaden, J.A.; Abrams, K.R.; Mayberry, J.F. The risk of colorectal cancer in ulcerative colitis: A meta-analysis. Gut 2001, 48, 526-535. [CrossRef]

5. Bernstein, C.N.; Blanchard, J.F.; Kliewer, E.; Wajda, A. Cancer risk in patients with inflammatory bowel disease: A populationbased study. Cancer 2001, 91, 854-862. [CrossRef]

6. Boland, P.M.; Yurgelun, M.B.; Boland, C.R. Recent progress in Lynch syndrome and other familial colorectal cancer syndromes. CA Cancer. J. Clin. 2018, 68, 217-231. [CrossRef]

7. Jasperson, K.W.; Tuohy, T.M.; Neklason, D.W.; Burt, R.W. Hereditary and familial colon cancer. Gastroenterology 2010, 138, 2044-2058. [CrossRef] [PubMed]

8. World Cancer Research Fund/American Institute for Cancer Research. Diet, Nutrition, Physical Activity and Colorectal Cancer; World Cnacer Research Fund International: London, UK, 2018; pp. 1-111.

9. Cancer Genome Atlas Network. Comprehensive molecular characterization of human colon and rectal cancer. Nature 2012, 487, 330. [CrossRef]

10. Pearlman, R.; Frankel, W.L.; Swanson, B.; Zhao, W.; Yilmaz, A.; Miller, K.; Bacher, J.; Bigley, C.; Nelsen, L.; Goodfellow, P.J.; et al. Prevalence and spectrum of germline cancer susceptibility gene mutations among patients with early-onset colorectal cancer. JAMA Oncol. 2017, 3, 464-471. [CrossRef] [PubMed]

11. Fearon, E.R. Molecular genetics of colorectal cancer. Annu. Rev. Pathol. 2011, 6, 479-507. [CrossRef] 
12. Yuan, W.; Li, X.; Liu, L.; Wei, C.; Sun, D.; Peng, S.; Jiang, L. Comprehensive analysis of lncRNA-associated ceRNA network in colorectal cancer. Biochem. Biophys. Res. Commun. 2019, 508, 374-379. [CrossRef]

13. Wu, Y.; Wang, X.; Wu, F.; Huang, R.; Xue, F.; Liang, G.; Tao, M.; Cai, P.; Huang, Y. Transcriptome profiling of the cancer, adjacent non-tumor and distant normal tissues from a colorectal cancer patient by deep sequencing. PLoS ONE 2012, 7, e41001. [CrossRef] [PubMed]

14. Fehlker, M.; Huska, M.R.; Jöns, T.; Andrade-Navarro, M.A.; Kemmner, W. Concerted down-regulation of immune-system related genes predicts metastasis in colorectal carcinoma. BMC Cancer 2014, 14, 64. [CrossRef]

15. O'Keefe, S.J. Diet, microorganisms and their metabolites, and colon cancer. Nat. Rev. Gastroenterol. Hepatol. 2016, 13, 691-706. [CrossRef] [PubMed]

16. Margetis, N.; Kouloukoussa, M.; Pavlou, K.; Vrakas, S.; Mariolis-Sapsakos, T. K-ras mutations as the earliest driving force in a subset of colorectal carcinomas. In Vivo 2017, 31, 527-542. [CrossRef]

17. Vogelstein, B.; Papadopoulos, N.; Velculescu, V.E.; Zhou, S.; Diaz, L.A., Jr.; Kinzler, K.W. Cancer genome landscapes. Science 2013, 339, 1546-1558. [CrossRef] [PubMed]

18. Leslie, A.; Carey, F.A.; Pratt, N.R.; Steele, R.J.C. The colorectal adenoma-carcinoma sequence. Br. J. Surg. 2002, 89, 845-860. [CrossRef] [PubMed]

19. Fearon, E.R.; Vogelstein, B. A genetic model for colorectal tumorigenesis. Cell 1990, 61, 759-767. [CrossRef]

20. Medema, J.P.; Vermeulen, L. Microenvironmental regulation of stem cells in intestinal homeostasis and cancer. Nature 2011, 474, 318-326. [CrossRef] [PubMed]

21. Mariani, F.; Sena, P.; Roncucci, L. Inflammatory pathways in the early steps of colorectal cancer development. World J. Gastroenterol. 2014, 20, 9716-9731. [CrossRef] [PubMed]

22. Legitimo, A.; Consolini, R.; Failli, A.; Orsini, G.; Spisni, R. Dendritic cell defects in the colorectal cancer. Hum. Vaccin. Immunother. 2014, 10, 3224-3235. [CrossRef]

23. Liaaen-Jensen, S. Marine Carotenoids. In Marine Natural Products; Chemical and Biological Perspectives; Scheuer, P.J., Ed.; Academic Press: New York, NY, USA, 1978; pp. 1-73. ISBN 0-12-624002-7.

24. Tavares, R.S.N.; Maria-Engler, S.S.; Colepicolo, P.; Debonsi, H.M.; Schäfer-Korting, M.; Marx, U.; Gaspar, L.R.; Zoschke, C. Skin irritation testing beyond tissue viability: Fucoxanthin effects on inflammation, homeostasis, and metabolism. Pharmaceutics 2020, 12, 136. [CrossRef]

25. Beppu, F.; Niwano, Y.; Tsukui, T.; Hosokawa, M.; Miyashita, K. Single and repeated oral dose toxicity study of fucoxanthin (FX), a marine carotenoid, in mice. J. Toxicol. Sci. 2009, 34, 501-510. [CrossRef]

26. Iio, K.; Okada, Y.; Ishikura, M. Single and 13-week oral toxicity study of fucoxanthin oil from microalgae in rats. Sokuhin Eiseigaku Zasshi 2011, 52, 183-189. [CrossRef] [PubMed]

27. Asai, A.; Yonekura, L.; Nagao, A. Low bioavailability of dietary epoxyxanthophylls in humans. Br. J. Nutr. 2008, 100, $273-277$. [CrossRef] [PubMed]

28. Hashimoto, T.; Ozaki, Y.; Mizuno, M.; Yoshida, M.; Nishitani, Y.; Azuma, T.; Komoto, A.; Maoka, T.; Tanino, Y.; Kanazawa, K. Pharmacokinetics of fucoxanthinol in human plasma after the oral administration of kombu extract. Br. J. Nutr. 2012, 107, 1566-1569. [CrossRef] [PubMed]

29. Hashimoto, T.; Ozaki, Y.; Taminato, M.; Das, S.K.; Mizuno, M.; Yoshimura, K.; Maoka, T.; Kanazawa, K. The distribution and accumulation of fucoxanthin and its metabolites after oral administration in mice. Br. J. Nutr. 2009, 102, 242-248. [CrossRef] [PubMed]

30. Yonekura, L.; Kobayashi, M.; Terasaki, M.; Nagao, A. Keto-carotenoids are the major metabolites of dietary lutein and fucoxanthin in mouse tissues. J. Nutr. 2010, 140, 1824-1831. [CrossRef]

31. Shiratori, K.; Ohgami, K.; Ilieva, I.; Jin, X.H.; Koyama, Y.; Miyashita, K.; Yoshida, K.; Kase, S.; Ohno, S. Effects of fucoxanthin on lipopolysaccharide-induced inflammation in vitro and in vivo. Exp. Eye Res. 2005, 81, 422-428. [CrossRef]

32. Hitoe, S.; Shimoda, H. Seaweed fucoxanthin supplementation improves obesity parameters in mild obese Japanese subjects. Func. Foods Health Dis. 2017, 7, 246-262. [CrossRef]

33. Mikami, N.; Hosokawa, M.; Miyashita, K.; Sohma, H.; Ito, Y.M.; Kokai, Y. Reduction of HbA1c levels by fucoxanthin-enriched akamoku oil possibly involves the thrifty allele of uncoupling protein 1 (UCP1): A randomised controlled trial in normal-weight and obese Japanese adults. J. Nutr. Sci. 2017, 6, e5. [CrossRef]

34. Grasa-López, A.; Miliar-Garcia, Á.; Quevedo-Corona, L.; Paniagua-Castro, N.; Escalona-Cardoso, G.; Reyes-Maldonado, E.; Jaramillo-Flores, M.E. Undaria pinnatifida and fucoxanthin ameliorate lipogenesis and markers of both inflammation and cardiovascular dysfunction in an animal model of diet-induced obesity. Mar. Drugs 2016, 14, 148. [CrossRef]

35. Karpiński, T.M.; Adamczak, A. Fucoxanthin-An antibacterial carotenoid. Antioxidants 2019, 8, 239. [CrossRef] [PubMed]

36. Sachindra, N.M.; Sato, E.; Maeda, H.; Hosokawa, M.; Niwano, Y.; Kohno, M.; Miyashita, K. Radical scavenging and singlet oxygen quenching activity of marine carotenoid fucoxanthin and its metabolites. J. Agric. Food Chem. 2007, 55, 8516-8522. [CrossRef] [PubMed]

37. Chen, S.J.; Lee, C.J.; Lin, T.B.; Peng, H.Y.; Liu, H.J.; Chen, Y.S.; Tseng, K.W. Protective effects of fucoxanthin on Ultraviolet B-induced corneal denervation and inflammatory pain in a rat model. Mar. Drugs 2019, 17, 152. [CrossRef] [PubMed]

38. Sugawara, T.; Matsubara, K.; Akagi, R.; Mori, M.; Hirata, T. Antiangiogenic activity of brown algae fucoxanthin and its deacetylated product, fucoxanthinol. J. Agric. Food Chem. 2006, 54, 9805-9810. [CrossRef] 
39. Ikeda, K.; Kitamura, A.; Machida, H.; Watanabe, M.; Negishi, H.; Hiraoka, J.; Nakano, T. Effect of Undaria pinnatifida (Wakame) on the development of cerebrovascular diseases in stroke-pone spontaneously hypertensive rats. Clin. Exp. Pharmacol. Physiol. 2003, 30, 44-48. [CrossRef] [PubMed]

40. Zhang, L.; Wang, H.; Fan, Y.; Gao, Y.; Li, X.; Hu, Z.; Ding, K.; Wang, Y.; Wang, X. Fucoxanthin provides neuroprotection in models of traumatic brain injury via the Nrf2-ARE and Nrf2-autophagy pathways. Sci. Rep. 2017, 7, 46763. [CrossRef] [PubMed]

41. Kim, J.M.; Araki, S.; Kim, D.J.; Park, C.B.; Takasuka, N.; Baba-Toriyama, H.; Ota, T.; Nir, Z.; Khachik, F.; Shimidzu, N.; et al. Chemopreventive effects of carotenoids and curcumins on mouse colon carcinogenesis after 1,2-dimethylhydrazine initiation. Carcinogenesis 1998, 19, 81-85. [CrossRef]

42. Nishino, H.; Murakoshi, M.; Tokuda, H.; Satomi, Y. Cancer prevention by carotenoids. Arch. Biochem. Biophys. 2009, 483, 165-168. [CrossRef]

43. Dawes, C.J. (Ed.) Marine Botany; John Wiley \& Sons, Inc.: New York, NY, USA, 1998; p. 480.

44. McHugh, D.J. A Guide to the Seaweed Industry; FAO Fisheries Technical Paper No.441; Food and Agriculture Organization of the United Nations: Rome, Italy, 2003; p. 105.

45. Holland, J. Seaweed on Track to Become Europe's Next Big Superfood Trend. 2016. Available online: https://www. seafoodsource.com/news/food-safety-health/seaweed-on-track-to-become-europe-s-next-big-superfood-trend (accessed on 27 February 2021).

46. Mintel Press Team. Seaweed-Flavoured Food and Drink Launches Increased by 147\% in Europe between 2011 and 2015. 2016. Available online: https:/ / www.mintel.com/press-centre/food-and-drink/seaweed-flavoured-food-and-drink-launchesincreased-by-147-in-europe-between-2011-and-2015 (accessed on 27 February 2021).

47. CEVA. Edible seaweed and microalgae-regulatory status in France and Europe. 19 March 2020 update. Available online: https://www.ceva-algues.com/en/document/edible-algae-regulatory-update/ (accessed on 27 February 2021).

48. Mori, K.; Ooi, T.; Hiraoka, M.; Oka, N.; Hamada, H.; Tamura, M.; Kusumi, T. Fucoxanthin and its metabolites in edible brown algae cultivated in deep seawater. Mar. Drugs 2004, 2, 63-72. [CrossRef]

49. Terasaki, M.; Hirose, A.; Narayan, B.; Baba, Y.; Kawagoe, C.; Yasui, H.; Saga, N.; Hosokawa, M.; Miyashita, K. Evaluation of recoverable functional lipid components of several brown seaweeds (phaeophyta) from Japan with special reference to fucoxanthin and fucosterol contents. J. Phycol. 2009, 45, 974-980. [CrossRef]

50. Terasaki, M.; Narayan, B.; Kamogawa, H.; Nomura, M.; Stephen, N.M.; Kawagoe, C.; Hosokawa, M.; Miyashita, K. Carotenoid profile of edible Japanese seaweeds: An improved HPLC method for separation of major carotenoids. J. Aquat. Food Prod. Technol. 2012, 21, 468-479. [CrossRef]

51. Terasaki, M.; Kuramitsu, Y.; Kojoma, M.; Kim, S.Y.; Tanaka, T.; Maeda, H.; Miyashita, K.; Kawagoe, C.; Kohno, S.; Mutoh, M. High fucoxanthin wakame (Undaria pinnatifida) prevents tumor microenvironment formation in an AOM/DSS mouse carcinogenic model. J. Func. Foods 2020, 64, 103709. [CrossRef]

52. Fung, A.; Hamid, N.; Lu, J. Fucoxanthin content and antioxidant properties of Undaria pinnatifida. Food Chem. 2013, 136, 1055-1062. [CrossRef] [PubMed]

53. Campbell, S.J.; Bité, J.S.; Burridge, T.R. Seasonal patterns in the photosynthetic capacity, tissue pigment and nutritional content of different developmental stages of Undaria pinnatifida (Phaeophyta: Laminariales) in Port Phillip Bay, south-eastern Australia. Bot. Mar. 1999, 42, 231-241. [CrossRef]

54. Shannon, E.; Abu-Ghannam, N. Optimisation of fucoxanthin extraction from Irish seaweeds by response surface methodology. J. Appl. Phycol. 2017, 29, 1027-1036. [CrossRef]

55. Sivagnanam, S.P.; Yin, S.; Choi, J.H.; Park, Y.B.; Woo, H.C.; Chun, B.S. Biological properties of fucoxanthin in oil recovered from two brown seaweeds using supercritical $\mathrm{CO}_{2}$ extraction. Mar. Drugs 2015, 13, 3422-3442. [CrossRef] [PubMed]

56. Sudhakar, M.P.; Ananthalakshmi, J.S.; Beena, B.N. Extraction, purification and study on antioxidant properties of fucoxanthin from brown seaweeds. J. Chem. Pharm. Res. 2013, 5, 169-175.

57. Jaswir, I.; Noviendri, D.; Salleh, H.M.; Miyashita, K. Fucoxanthin extractions of brown seaweeds and analysis of their lipid fraction in methanol. Food Sci. Technol. Res. 2012, 18, 251-257. [CrossRef]

58. Fariman, G.A.; Shastan, S.J.; Zahedi, M.M. Seasonal variation of total lipid, fatty acids, fucoxanthin content, and antioxidant properties of two tropical brown algae (Nizamuddinia zanardinii and Cystoseira indica) from Iran. J. Appl. Phycol. 2016, 28, 1323-1331. [CrossRef]

59. Susanto, E.; Fahmi, A.S.; Abe, M.; Hosokawa, M.; Miyashita, K. Lipids, fatty acids, and fucoxanthin content from template and tropical brown seaweeds. Aquat. Procedia 2016, 7, 66-75. [CrossRef]

60. Kanazawa, K.; Ozaki, Y.; Hashimoto, T.; Das, S.K.; Matsushita, S.; Hirano, M.; Okada, T.; Komoto, A.; Mori, N.; Nakatsuka, M. Commercial-scale preparation of biofunctional fucoxanthin from waste parts of brown sea algae Laminalia japonica. Food Sci. Technol. Res. 2008, 14, 573-582. [CrossRef]

61. Xu, S.; Liao, W.C.; Chen, W.; Kang, B.; Chen, J.; Lin, Y. Study of microwave synergistic enzyme method for extraction from Laminaria Japonica by response surface methodology. Earth Environ. Sci. 2018, 146, 012077. [CrossRef]

62. Rajauria, G.; Foley, B.; Abu-Ghannam, N. Characterization of dietary fucoxanthin from Himanthalia elongata brown seaweed. Food Res. Int. 2017, 99, 995-1001. [CrossRef]

63. Amorim-Carrilho, K.; Lage-Yusty, M.A.; López-Hernández, J. Variation of bioactive compounds in dried seaweed Himanthalia elongata subjected to different culinary processes. CyTA-J. Food 2014, 12, 336-339. [CrossRef] 
64. Mise, T.; Ueda, M.; Yasumoto, T. Production of fucoxanthin-rich powder from Cladosiphon okamuranus. Adv. J. Food Sci. Technol. 2011, 3, 73-76.

65. Jaswir, I.; Noviendri, D.; Salleh, H.M.; Taher, M.; Miyashita, K. Isolation of fucoxanthin and fatty acids analysis of Padina australis and cytotoxic effect of fucoxanthin on human lung cancer (H1299) cell lines. African J. Biotechnol. 2011, 10, $18855-18862$.

66. Miyashita, K.; Takagi, T. Tocopherol content of Japanese algae and its seasonal variation. Agric. Biol. Chem. 1987, 51, 3115-3118. [CrossRef]

67. Lohr, M.; Wilhelm, C. Algae displaying the diadinoxanthin cycle also possess the violaxanthin cycle. Proc. Natl. Acad. Sci. USA 1999, 96, 8784-8789. [CrossRef]

68. Petrushkina, M.; Gusev, E.; Sorokin, B.; Zotko, N.; Mamaeva, A.; Filimonova, A.; Kulikovskiy, M.; Maltsev, Y.; Yampolsky, I.; Guglya, E.; et al. Fucoxanthin production by heterokont microalgae. Algal Res. 2017, 24, 387-393. [CrossRef]

69. Kim, S.M.; Kang, S.W.; Kwon, O.; Chung, D.; Pan, C.H. Fucoxanthin as a major carotenoid in Isochrysis aff. Galbana: Characterization of extraction for commercial application. J. Korean Soc. Appl. Biol. Chem. 2012, 55, 477-483. [CrossRef]

70. Xia, S.; Wang, K.; Wan, L.; Li, A.; Hu, Q.; Zhang, C. Production, characterization, and antioxidant activity of fucoxanthin from the marine diatom Odontella Aurita. Mar. Drugs. 2013, 11, 2667-2681. [CrossRef]

71. Teramukai, K.; Kakui, S.; Beppu, F.; Hosokawa, M.; Miyashita, K. Effective extraction of carotenoids from brown seaweeds and vegetable leaves with edible oils. Innov. Food Sci. Emerg. Technol. 2020, 60, 102302. [CrossRef]

72. Lourenço-Lopes, C.; Garcia-Oliveira, P.; Carpena, M.; Fraga-Corral, M.; Jimenez-Lopez, C.; Pereira, A.G.; Prieto, M.A.; SimalGandara, J. Scientific approaches on extraction, purification and stability for the commercialization of fucoxanthin recovered from brown algae. Foods 2020, 9, 1113. [CrossRef] [PubMed]

73. Okada, T.; Mizuno, Y.; Sibayama, S.; Hosokawa, M.; Miyashita, K. Antiobesity effects of Undaria lipid capsules prepared with scallop phospholipid. J. Food Sci. 2011, 76, H2-H6. [CrossRef]

74. Mok, I.K.; Yoon, J.R.; Pan, C.H.; Kim, S.M. Development, quantification, method validation, and stability study of a novel fucoxanthin-fortified milk. J. Agric. Food Chem. 2016, 64, 6196-6202. [CrossRef] [PubMed]

75. Sasaki, K.; Ishihara, K.; Oyamada, C.; Sato, A.; Fukushi, A.; Arakane, T.; Motoyama, M.; Yamazaki, M.; Mitsumoto, M. Effects of fucoxanthin addition to ground chicken breast meat on lipid and colour stability during chilled storage, before and after cooking Asian-Australas. J. Anim. Sci. 2008, 21, 1067-1072. [CrossRef]

76. Sugimura, R.; Suda, M.; Sho, A.; Takahashi, T.; Sashima, T.; Abe, M.; Hosokawa, M.; Miyashita, K. Stability of fucoxanthin in dried Undaria pinnatifida (wakame) and baked products (scones) containing wakame powder. Food Sci. Technol. Res. 2012, 18, 687-693. [CrossRef]

77. Robertson, R.C.; Gracia Mateo, M.R.; O'Grady, M.N.; Guihéneuf, F.; Stengel, D.B.; Ross, R.P.; Fitzgerald, G.F.; Kerry, J.P.; Stanton, C. An assessment of the techno-functional and sensory properties of yoghurt fortified with a lipid extract from the microalga Pavlova lutheri. Innov. Food Sci. Emerg. Technol. 2016, 37, 237-246. [CrossRef]

78. Nishibori, N.; Itoh, M.; Kashiwagi, M.; Arimochi, H.; Morita, K. In vitro cytotoxic effect of ethanol extract prepared from sporophyll of Undaria pinnatifida on human colorectal cancer cells. Phytother. Res. 2012, 26, 191-196. [CrossRef] [PubMed]

79. Kim, A.D.; Kang, K.A.; Piao, M.J.; Kim, K.C.; Zheng, J.; Yao, C.W.; Cha, J.W.; Hyun, C.L.; Boo, S.J.; Lee, N.H.; et al. Dictyopteris undulata extract induces apoptosis in human colon cancer cells. Biotechnol. Bioproc. Eng. 2014, 19, 419-425. [CrossRef]

80. Kang, K.A.; Kim, J.K.; Jeong, Y.J.; Na, S.Y.; Hyun, J.W. Dictyopteris undulata extract induces apoptosis via induction of endoplasmic reticulum stress in human colon cancer cells. J. Cancer Prev. 2014, 19, 118-124. [CrossRef]

81. Ye, B.R.; Kim, J.; Kim, M.S.; Jang, J.; Oh, C.; Kang, D.H.; Qian, Z.J.; Jung, W.K.; Choi, I.W.; Heo, S.J. Induction of apoptosis by the tropical seaweed Pylaiella littoralis in HT-29 cells via the mitochondrial and MAPK pathways. Ocean Sci. J. 2013, 48, 338-348. [CrossRef]

82. Mahmoud, A.M.; Abdella, E.M.; El-Derby, A.M.; Abdella, E.M. Protective effects of Turbinaria ornata and Padina pavonia against azoxymethane-induced colon carcinogenesis through modulation of PPAR gamma, NF-kB and oxidative stress. Phytother. Res. 2015, 29, 737-748. [CrossRef]

83. Mhadhebi, L.; Laroche-Clary, A.; Robert, J.; Bouraoui, A. Antioxidant, anti-inflammatory, and antiproliferative activities of organic fractions from the Mediterranean brown seaweed Cystoseira sedoides. Can. J. Physiol. Pharmacol. 2011, 89, 911-921. [CrossRef]

84. Terasaki, M.; Takahashi, S.; Nishimura, R.; Kubota, A.; Kojima, H.; Ohta, T.; Hamada, J.; Kuramitsu, Y.; Maeda, H.; Miyashita, K.; et al. A marine carotenoid of fucoxanthinol accelerates the growth of human pancreatic cancer PANC-1 cells. Nutr. Cancer 2021, 1-16. [CrossRef]

85. Yokoyama, R.; Kojima, H.; Takai, R.; Ohta, T.; Maeda, H.; Miyashita, K.; Mutoh, M.; Terasaki, M. Effects of CLIC4 on fucoxanthinolinduced apoptosis in human colorectal cancer cells. Nutr Cancer 2021, 73, 889-898. [CrossRef]

86. Terasaki, M.; Maeda, H.; Miyashita, K.; Mutoh, M. Induction of anoikis in human colorectal cancer cells by fucoxanthinol. Nutr. Cancer 2017, 69, 1043-1052. [CrossRef]

87. Tamura, S.; Narita, T.; Fujii, G.; Miyamoto, S.; Hamoya, T.; Kurokawa, Y.; Takahashi, M.; Miki, K.; Matsuzawa, Y.; Komiya, M.; et al. Inhibition of NF-kappaB transcriptional activity enhances fucoxanthinol-induced apoptosis in colorectal cancer cells. Genes Environ. 2019, 41, 1. [CrossRef] [PubMed]

88. Lopes-Costa, E.; Abreu, M.; Gargiulo, D.; Roche, E.; Ramos, A.A. Anticancer effects of seaweed compounds fucoxanthin and phloroglucinol, alone and in combination with 5-fluorouracil in colon cells. J. Toxicol. Environ. Health A 2017, 80, 776-787. [CrossRef] [PubMed] 
89. Das, S.K.; Hashimoto, T.; Shimizu, K.; Yoshida, T.; Sakai, T.; Sowa, Y.; Komoto, A.; Kanazawa, K. Fucoxanthin induces cell cycle arrest at $\mathrm{G}_{0} / \mathrm{G}_{1}$ phase in human colon carcinoma cells through up-regulation of p21 WAF1/Cip1. Biochim. Biophys. Acta 2005, 1726, 328-335. [CrossRef] [PubMed]

90. Hosokawa, M.; Kudo, M.; Maeda, H.; Kohno, H.; Tanaka, T.; Miyashita, K. Fucoxanthin induces apoptosis and enhances the antiproliferative effect of the PPAR $\gamma$ ligand, troglitazone, on colon cancer cells. Biochim. Biophys. Acta 2004, 1675, 113-119. [CrossRef] [PubMed]

91. Konishi, I.; Hosokawa, M.; Sashima, T.; Kobayashi, H.; Miyashita, K. Halocynthiaxanthin and fucoxanthinol isolated from Halocynthia roretzi induce apoptosis in human leukemia, breast and colon cancer cells. Comp. Biochem. Physiol. C Toxicol. Pharmacol. 2006, 142, 53-59. [CrossRef] [PubMed]

92. Manmuan, S.; Manmuan, P. Fucoxanthin enhances 5-FU chemotherapeutic efficacy in colorectal cancer cells by affecting MMP-9 invasive proteins. J. Appl. Pharm. Sci. 2019, 9, 007-014. [CrossRef]

93. Takahashi, K.; Hosokawa, M.; Kasajima, H.; Hatanaka, K.; Kudo, K.; Shimoyama, N.; Miyashita, K. Anticancer effects of fucoxanthin and fucoxanthinol on colorectal cancer cell lines and colorectal cancer. Oncol. Lett. 2015, 10, 1463-1467. [CrossRef] [PubMed]

94. Dalerba, P.; Dylla, S.J.; Park, I.K.; Liu, R.; Wang, X.; Cho, R.W.; Hoey, T.; Gurney, A.; Huang, E.H.; Simeone, D.M.; et al. Phenotypic characterization of human colorectal cancer stem cells. Proc. Natl. Acad. Sci. USA 2007, 104, 10158-10163. [CrossRef]

95. Vermeulen, L.; Todaro, M.; de Sousa Mello, F.; Sprick, M.R.; Kemper, K.; Alea, M.P.; Richel, D.J.; Stassi, G.; Medema, J.P. Single-cell cloning of colon cancer stem cells reveals a multi-lineage differentiation capacity. Proc. Natl. Acad. Sci. USA 2008, 105, 13427-13432. [CrossRef] [PubMed]

96. Kanwar, S.S.; Yu, Y.; Nautiyal, J.; Patel, B.B.; Majumdar, A.P.N. The Wnt/ $\beta$-catenin pathway regulates growth and maintenance of colonospheres. Mol. Cancer 2010, 9, 212. [CrossRef] [PubMed]

97. Terasaki, M.; Maeda, H.; Miyashita, K.; Tanaka, T.; Miyamoto, S.; Mutoh, M. A marine bio-functional lipid, fucoxanthinol, attenuates human colorectal cancer stem-like cell tumorigenicity and sphere formation. J. Clin. Biochem. Nutr. 2017, 61, 25-32. [CrossRef]

98. Terasaki, M.; Mima, M.; Kudoh, S.; Endo, T.; Maeda, H.; Hamada, J.; Osada, K.; Miyashita, K.; Mutoh, M. Glycine and succinic acid are effective indicators of the suppression of epithelial-mesenchymal transition by fucoxanthinol in colorectal cancer stem-like cells. Oncol. Rep. 2018, 40, 414-424. [CrossRef]

99. Terasaki, M.; Ogawa, Y.; Endo, T.; Maeda, H.; Hamada, J.; Osada, K.; Miyashita, K.; Mutoh, M. Glycine is a predictor for a suppressive effect of fucoxanthinol on colonosphere formation under hypoxia. Anticancer Res. 2018, 38, 2169-2179. [CrossRef]

100. De la Mare, J.; Sterrenberg, J.N.; Sukhthankar, M.G.; Chiwakata, M.T.; Beukes, D.R.; Blatch, G.L.; Edkins, A.L. Assessment of potential anti-cancer stem cell activity of marine algal compounds using an in vitro mammosphere assay. Cancer Cell Int. 2013, 13, 39. [CrossRef] [PubMed]

101. Kong, Z.L.; Kao, N.J.; Hu, J.Y.; Wu, C.S. Fucoxanthin-rich brown algae extract decreases inflammation and attenuates colitisassociated colon cancer in mice. J. Food Nutr. Res. 2016, 4, 137-147. [CrossRef]

102. Son, Y.S.; Ullah, H.M.A.; Elfadl, A.K.; Ghim, S.G.; Chung, M.J.; Kim, Y.D.; Lee, E.J.; Kang, K.K.; Jeong, K.S. Inhibition of formation of azoxymethane-induced colonic aberrant crypt foci in rats by edible green algae Capsosiphon fulvescens and brown algae Hizikia fusiforme. In Vivo 2018, 32, 101-108. [CrossRef]

103. Das, S.K.; Hasshimoto, T.; Baba, M.; Nishino, H.; Komoto, A.; Kanazawa, K. Japanese kelp (kombu) extract suppressed the formation of aberrant crypt foci in azoxymethane challenged mouse colon. J. Clin. Biochem. Nutr. 2006, 38, 119-125. [CrossRef]

104. Reddy, B.S.; Numoto, S.; Choi, C.I. Effects of dietary Laminaria angustata (brown seaweed) on azoxymethane-induced intestinal carcinogenesis in male F344 rats. Nutr. Cancer 1985, 7, 59-64. [CrossRef]

105. Buchheit, C.L.; Weigel, K.J.; Schafer, Z.T. Cancer cell survival during detachment from the ECM: Multiple barriers to tumour progression. Nat. Rev. Cancer 2014, 14, 632-641. [CrossRef] [PubMed]

106. Horbinski, C.; Mojesky, C.; Kyprianou, N. Live free or die: Tales of homeless (cell) in cancer. Am. J. Pathol. 2010, 177, 1044-1052. [CrossRef] [PubMed]

107. Paoli, P.; Giannoni, E.; Chiarugi, P. Anoikis molecular pathways and its role in cancer progression. Biochim. Biophys. Acta 2013, 1833, 3481-3498. [CrossRef]

108. Terasaki, M.; Iida, T.; Kikuchi, F.; Tamura, K.; Endo, T.; Kuramitsu, Y.; Tanaka, T.; Maeda, H.; Miyashita, K.; Mutoh, M. Fucoxanthin potentiates anoikis in colon mucosa and prevents carcinogenesis in AOM/DSS model mice. J. Nutr. Biochem. 2019, 64, 198-205. [CrossRef]

109. Terasaki, M.; Ikuta, M.; Kojima, H.; Tanaka, T.; Maeda, H.; Miyashita, K.; Mutoh, M. Dietary fucoxanthin induces anoikis in colorectal adenocarcinoma by suppressing integrin signaling in a murine colorectal cancer model. J. Clin. Med. 2020, 9, 90. [CrossRef]

110. Findlay, V.J.; Wang, C.; Watson, D.K.; Camp, E.R. Epithelial to mesenchymal transition and the cancer stem cell phenotype: Insights from cancer biology with therapeutic implications for colorectal cancer. Cancer Gene Ther. 2014, 21, 181-187. [CrossRef]

111. Terasaki, M.; Masaka, S.; Fukada, C.; Houzaki, M.; Endo, T.; Tanaka, T.; Maeda, H.; Miyashita, K.; Mutoh, M. Salivary glycine is a significant predictor for the attenuation of polyp and tumor microenvironment formation by fucoxanthin in AOM/DSS mice. In Vivo 2019, 33, 365-374. [CrossRef] [PubMed] 
112. Terasaki, M.; Kimura, R.; Kubota, A.; Kojima, H.; Tanaka, T.; Maeda, H.; Miyashita, K.; Mutoh, M. Continuity of tumor microenvironmental suppression in AOM/DSS mice by fucoxanthin may be able to track with salivary glycine. In Vivo 2020, 34, 3205-3215. [CrossRef] [PubMed]

113. Garrett, W.S. The gut microbiota and colon cancer. Science 2019, 364, 1133-1135. [CrossRef]

114. Gagnière, J.; Raisch, J.; Veziant, J.; Barnich, N.; Bonnet, R.; Buc, E.; Bringer, M.A.; Pezet, D.; Bonnet, M. Gut microbiota imbalance and colorectal cancer. World J. Gastroenterol. 2016, 22, 501-518. [CrossRef]

115. Terasaki, M.; Uehara, O.; Ogasa, S.; Sano, T.; Kubota, A.; Kojima, H.; Tanaka, T.; Maeda, H.; Miyashita, K.; Mutoh, M. Alteration of fecal microbiota by fucoxanthin results in prevention of colorectal cancer in AOM/DSS mice. Carcinogenesis 2021, 42, 210-219. [CrossRef]

116. Terasaki, M.; Matsumoto, N.; Hashimoto, R.; Endo, T.; Maeda, H.; Hamada, J.; Osada, K.; Miyashita, K.; Mutoh, M. Fucoxanthin administration delays occurrence of tumors in xenograft mice by colonospheres, with an anti-tumor predictor of glycine. J. Clin. Biochem. Nutr. 2019, 64, 52-58. [CrossRef]

117. Terasaki, M.; Hamoya, T.; Kubota, A.; Kojima, H.; Tanaka, T.; Maeda, H.; Miyashita, K.; Mutoh, M. Fucoxanthin prevents colorectal cancer development in dextran sodium sulfate-treated Apc Min/+ mice. Anticancer Res. 2021, 41, 1299-1305. [CrossRef]

118. Jeon, S.M.; Kim, H.J.; Woo, M.N.; Lee, M.K.; Shin, Y.C.; Park, Y.B.; Choi, M.S. Fucoxanthin-rich seaweed extract suppresses body weight gain and improves lipid metabolism in high-fat-fed C57BL/6J mice. Biotechnol. J. 2010, 5, 961-969. [CrossRef] [PubMed]

119. Woo, M.N.; Jeon, S.M.; Shin, Y.C.; Lee, M.K.; Kang, M.A.; Choi, M.S. Anti-obese property of fucoxanthin is partly mediated by altering lipid-regulating enzymes and uncoupling proteins of visceral adipose tissue in mice. Mol. Nutr. Food Res. 2009, 53, 1603-1611. [CrossRef] [PubMed]

120. Murakami, S.; Hirazawa, C.; Ohya, T.; Yoshikawa, R.; Mizutani, T.; Ma, N.; Moriyama, M.; Ito, T.; Matsuzaki, C. The edible brown seaweed Sargassum horneri (Turner) C. Agardh ameliorates high-fat diet-induced obesity, diabetes, and hepatic steatosis in mice. Nutrients 2021, 13, 551. [CrossRef] [PubMed]

121. Awang, A.N.; Ng, J.L.; Matanjun, P.; Sulaiman, M.R.; Tan, T.S.; Ooi, Y.B.H. Anti-obesity property of the brown seaweed Sargassum polycystum using an in vivo animal model. J. Appl. Phycol. 2014, 26, 1043-1048. [CrossRef]

122. Germoush, M.O. Antioxidant and anti-inflammatory effects of Padina pavonia and Turbenaria ornate in streptozotocin/nicotinamide diabetic rats. Life Sci. J. 2013, 10, 1265-1271.

123. Kang, S.I.; Shin, H.S.; Kim, H.M.; Yoon, S.A.; Kang, S.W.; Kim, J.H.; Ko, H.C.; Kim, S.J. Petalonia binghamiae extract and its constituent fucoxanthin ameliorate high-fat diet-induced obesity by activating AMP-activated protein kinase. J. Agric. Food Chem. 2012, 60, 3389-3395. [CrossRef] [PubMed]

124. Maeda, H.; Hosokawa, M.; Sashima, T.; Funayama, K.; Miyashita, K. Fucoxanthin from edible seaweed, Undaria pinnatifida, shows antiobesity effect through UCP1 expression in white adipose tissues. Biochem. Biophys. Res. Commun. 2005, 332, $392-397$. [CrossRef]

125. Maeda, H.; Hosokawa, M.; Sashima, T.; Funayama, K.; Miyashita, K. Effect of medium-chain triacylglycerols on anti-obesity effect of fucoxanthin. J. Oleo Sci. 2007, 56, 615-621. [CrossRef]

126. Maeda, H.; Hosokawa, M.; Sashima, T.; Miyashita, K. Dietary combination of fucoxanthin and fish oil attenuates the weight gain of white adipose tissue and decreases blood glucose in obese/diabetic KK-Ay mice. J. Agric. Food Chem. 2007, 55, 7701-7706. [CrossRef] [PubMed]

127. Maeda, H.; Hosokawa, M.; Sashima, T.; Murakami-Funayama, K.; Miyashita, K. Anti-obesity and anti-diabetic effects of fucoxanthin on diet-induced obesity conditions in a murine model. Mol. Med. Rep. 2009, 2, 897-902. [CrossRef]

128. Hosokawa, M.; Miyashita, T.; Nishikawa, S.; Emi, S.; Tsukui, T.; Beppu, F.; Okada, T.; Miyashita, K. Fucoxanthin regulates adipocytokine mRNA expression in white adipose tissue of diabetic/obese KK-Ay mice. Arch. Biochem. Biophys. 2010, 504, 17-25. [CrossRef]

129. Beppu, F.; Hosokawa, M.; Yim, M.J.; Shinoda, T.; Miyashita, K. Down-regulation of hepatic stearoyl-CoA desaturase-1 expression by fucoxanthin via leptin signaling in diabetic/obese KK-A(y) mice. Lipids 2013, 48, 449-455. [CrossRef] [PubMed]

130. Nishikawa, S.; Hosokawa, M.; Miyashita, K. Fucoxanthin promotes translocation and induction of glucose transporter 4 in skeletal muscles of diabetic/obese KKA(y) mice. Phytomedicine 2012, 19, 389-394. [CrossRef]

131. Woo, M.N.; Jeon, S.M.; Kim, H.J.; Lee, M.K.; Shin, S.K.; Shin, Y.C.; Park, Y.B.; Choi, M.S. Fucoxanthin supplementation improves plasma and hepatic lipid metabolism and blood glucose concentration in high-fat fed C57BL/6N mice. Chem. Biol. Interact. 2010, 186, 316-322. [CrossRef] [PubMed]

132. Park, H.J.; Lee, M.K.; Park, Y.B.; Shin, Y.C.; Choi, M.S. Beneficial effects of Undaria pinnatifida ethanol extract on diet-inducedinsulin resistance in C57BL/6J mice. Food Chem. Toxicol. 2011, 49, 727-733. [CrossRef]

133. Yang, Y.P.; Tong, Q.Y.; Zheng, S.H.; Zhou, M.D.; Zeng, Y.M.; Zhou, T.T. Anti-inflammatory effect of fucoxanthin on dextran sulfate sodium-induced colitis in mice. Nat. Prod. Res. 2020, 34, 1791-1795. [CrossRef]

134. Kim, J.Y.; Yu, D.Y.; Kim, J.A.; Choi, E.Y.; Lee, C.Y.; Hong, Y.H.; Kim, C.W.; Lee, S.S.; Choi, I.S.; Cho, K.K. Effects of Undaria pinnatifida and Laminaria japonica on rat's intestinal microbiota and metabolite. J. Nutr. Food Sci. 2016, 6, 3. [CrossRef]

135. Sun, X.; Zhao, H.; Liu, Z.; Sun, X.; Zhang, D.; Wang, S.; Xu, Y.; Zhang, G.; Wang, D. Modulation of gut microbiota by fucoxanthin during alleviation of obesity in high-fat diet-fed mice. J. Agric. Food Chem. 2020, 68, 5118-5128. [CrossRef] [PubMed]

136. Guo, B.; Yang, B.; Pang, X.; Chen, T.; Chen, F.; Cheng, K.W. Fucoxanthin modulates cecal and fecal microbiota differently based on diet. Food Funct. 2019, 10, 5644-5655. [CrossRef] 
137. Liu, Z.; Sun, X.; Sun, X.; Wang, S.; Xu, Y. Fucoxanthin isolated from Undaria pinnatifida can interact with Escherichia coli and lactobacilli in the intestine and inhibit the growth of pathogenic bacteria. J. Ocean Univ. China 2019, 18, 926-932. [CrossRef]

138. Haslam, D.; Sattar, N.; Lean, M. ABC of obesity. Obesity-time to wake up. BMJ 2006, 333, 640-642. [CrossRef] [PubMed]

139. Calle, E.E.; Rodriguez, C.; Walker-Thurmond, K.; Thun, M.J. Overweight, obesity, and mortality from cancer in a prospective cohort of U.S. adults. N. Engl. J. Med. 2003, 348, 1625-1638. [CrossRef] [PubMed]

140. Renehan, A.G.; Tyson, M.; Egger, M.; Heller, R.F.; Zwahlen, M. Body-mass index and incidence of cancer: A systematic review and meta-analysis of prospective observational studies. Lancet 2008, 371, 569-578. [CrossRef]

141. Gallagher, E.J.; LeRoith, D. Obesity and diabetes: The increased risk of cancer and cancer-related mortality. Physiol. Rev. 2015, 95, 727-748. [CrossRef] [PubMed]

142. Larsson, S.C.; Orsini, N.; Wolk, A. Diabetes mellitus and risk of colorectal cancer: A meta-analysis. J. Natl. Cancer Inst. 2005, 97, 1679-1687. [CrossRef]

143. Blüher, M. Adipokines-removing road blocks to obesity and diabetes therapy. Mol. Metab. 2014, 3, 230-240. [CrossRef]

144. Ohashi, K.; Shibata, R.; Murohara, T.; Ouchi, N. Role of anti-inflammatory adipokines in obesity-related diseases. Trends Endocrinol. Metab. 2014, 25, 348-355. [CrossRef]

145. Ouchi, N.; Parker, J.L.; Lugus, J.J.; Walsh, K. Adipokines in inflammation and metabolic disease. Nat. Rev. Immunol. 2011, 11, 85-97. [CrossRef]

146. Matsuzawa, Y. The metabolic syndrome and adipocytokines. FEBS Lett. 2006, 580, 2917-2921. [CrossRef] [PubMed]

147. Ferrante, A.W., Jr. Obesity-induced inflammation: A metabolic dialogue in the language of inflammation. J. Intern. Med. 2007, 262, 408-414. [CrossRef] [PubMed]

148. Brennan, C.A.; Garrett, W.S. Gut microbiota, inflammation, and colorectal cancer. Annu. Rev. Microbiol. 2016, 70, 395-411. [CrossRef]

149. Beaugerie, I.; Itzkowitz, S.H. Cancers complicating inflammatory bowel disease. N. Engl. J. Med. 2015, 372, 1441-1452. [CrossRef]

150. Hanahan, D.; Weinberg, R.A. Hallmarks of cancer: The next generation. Cell 2011, 144, 646-674. [CrossRef]

151. Dray, A. Inflammatory mediators of pain. Br. J. Anaesth. 1995, 75, 125-131. [CrossRef] [PubMed]

152. Hotamisligil, G.S. Inflammation and metabolic disorders. Nature 2006, 444, 860-867. [CrossRef] [PubMed]

153. Newton, K.; Dixit, V.M. Signaling in innate immunity and inflammation. Cold Spring Harb Perspect. Biol. 2012, 4, a006049. [CrossRef] [PubMed]

154. Matosevic, P.; Klepac-Pulanic, T.; Kinda, E.; Augustin, G.; Brcic, I.; Jakic-Razumovic, J. Immunohistochemical expression of 8-oxo-7,8-dihydro-2'-deoxyguanosine in cytoplasm of tumour and adjacent normal mucosa cells in patients with colorectal cancer World J. Surg. Oncol. 2015, 13, 241. [CrossRef] [PubMed]

155. Guz, J.; Foksinski, M.; Siomek, A.; Gackowski, D.; Rozalski, R.; Dziaman, T.; Szpila, A.; Olinski, R. The relationship between 8-oxo-7,8-dihydro-2'-deoxyguanosine level and extent of cytosine methylation in leukocytes DNA of healthy subjects and in patients with colon adenomas and carcinomas. Mut. Res. 2008, 640, 170-173. [CrossRef] [PubMed]

156. Van der Logt, E.M.J.; Roelofs, H.M.J.; Wobbes, T.; Nagengast, F.M.; Peters, W.H.M. High oxygen radical production in patients with sporadic colorectal cancer. Free Radic. Biol. Med. 2005, 39, 182-187. [CrossRef] [PubMed]

157. Moret-Tatay, I.; Iborra, M.; Cerrillo, E.; Tortosa, L.; Nos, P.; Beltrán, B. Possible biomarkers in blood for Crohn's disease: Oxidative stress and microRNAs-Current evidences and further aspects to unravel. Oxid. Med. Cell Longev. 2016, 2016, 2325162. [CrossRef] [PubMed]

158. Piechota-Polanczyk, A.; Fichna, J. Review article: The role of oxidative stress in pathogenesis and treatment of inflammatory bowel diseases. Naunyn Schmiedebergs Arch. Pharmacol. 2014, 387, 605-620. [CrossRef] [PubMed]

159. Basak, D.; Uddin, M.N.; Hancock, J. The role of oxidative stress and its counteractive utility in colorectal cancer (CRC). Cancers 2020, 12, 3336. [CrossRef]

160. Parisi, E.; Sorolla, A.; Montal, R.; González-Resina, R.; Novell, A.; Salud, A.; Sorolla, M.A. Prognostic factors involved in the epithelial-mesenchymal transition process in colorectal cancer have a preponderant role in oxidative stress: A systematic review and meta-analysis. Cancers 2020, 12, 3330. [CrossRef]

161. Kawanishi, S.; Hiraku, Y.; Pinlaor, S.; Ma, N. Oxidative and nitrative DNA damage in animals and patients with inflammatory diseases in relation to inflammation-related carcinogenesis. Biol. Chem. 2006, 387, 365-372. [CrossRef]

162. Szatrowski, T.P.; Nathan, C.F. Production of large amounts of hydrogen peroxide by human tumor cells. Cancer Res. 1991, 51, 794-798.

163. Oberley, T.D.; Oberley, L.W. Antioxidant enzyme levels in cancer. Histol. Histopathol. 1997, 12, 525-535. [PubMed]

164. Kumar, B.; Koul, S.; Khandrika, L.; Meacham, R.B.; Koul, H.K. Oxidative stress is inherent in prostate cancer cells and is required for aggressive phenotype. Cancer Res. 2008, 68, 1777-1785. [CrossRef] [PubMed]

165. Martinez-Sánchez, G.; Giuliani, A. Cellular redox status regulates hypoxia inducible factor-1 activity. Role in tumour development. J. Exp. Clin. Cancer Res. 2007, 26, 39-50.

166. Adibov, M.; Ramazanov, Z.; Seifulla, R.; Grachev, S. The effects of Xanthigen in the weight management of obese premenopausal women with non-alcoholic fatty liver disease and normal liver fat. Diabetes Obes. Metab. 2010, 12, 72-81. [CrossRef]

167. Miyashita, K.; Beppu, F.; Hosokawa, M.; Liu, X.; Wang, S. Nutraceutical characteristics of the brown seaweed carotenoid fucoxanthin. Arch. Biochem. Biophys. 2020, 686, 108364. [CrossRef] [PubMed] 
168. Seale, P.; Kajimura, S.; Spiegelman, B.M. Transcriptional control of brown adipocyte development and physiological function-of mice and men. Genes Dev. 2009, 23, 788-797. [CrossRef] [PubMed]

169. Brestoff, J.R.; Artis, D. Immune regulation of metabolic homeostasis in health and disease. Cell 2015, 161, 146-160. [CrossRef]

170. Harms, M.; Seale, P. Brown and beige fat: Development, function and therapeutic potential. Nat. Med. 2013, 19, 1252-1263. [CrossRef] [PubMed]

171. Baldrick, F.R.; McFadden, K.; Ibars, M.; Sung, C.; Moffatt, T.; Megarry, K.; Thomas, K.; Mitchell, P.; Wallace, J.M.W.; Pourshahidi, L.K.; et al. Impact of a (poly)phenol-rich extract from the brown algae Ascophyllum nodosum on DNA damage and antioxidant activity in an overweight or obese population: A randomized controlled trial. Am. J. Clin. Nutr. 2018, 108, 688-700. [CrossRef]

172. Lacoviello, L.; Zito, F.; Rago, L.; Di Castelnuovo, A.; De Curtis, A.; Zappacosta, B.; de Gaetano, G.; Donati, M.B.; Cerletti, C. Prolong administration of Ascophyllum nodosum to healthy human volunteers and cardiovascular risk. Nutrafoods 2013, 12, 137-144. [CrossRef]

173. Tanemura, Y.; Yamanaka-Okumura, H.; Sakuma, M.; Nii, Y.; Taketani, Y.; Takeda, E. Effects of the intake of Undaria pinnatifida (Wakame) and its sporophylls (Mekabu) on postprandial glucose and insulin metabolism. J. Med. Investig. 2014, 61, 291-294. [CrossRef] [PubMed]

174. Yoshinaga, K.; Mitamura, R. Effects of Undaria pinnatifida (Wakame) on postprandial glycemia and insulin levels in humans: A randomized crossover trial. Plant Foods Hum. Nutr. 2019, 74, 461-467. [CrossRef] [PubMed]

175. Teas, J.; Baldeón, M.E.; Chiriboga, D.E.; Davis, J.R.; Sarriés, A.J.; Braverman, L.E. Could dietary seaweed reverse the metabolic syndrome? Asia Pac. J. Clin. Nutr. 2009, 18, 145-154.

176. Izaola, O.; Primo, D.; Bargués, D.R.; Martín-Diana, A.B.; Villaluenga, C.M.; Miranda, J.; de Luis Román, D. Effects of a snack enriched with carob and Undaria pinnatifida (wakame) on metabolic parameters in a double blind, randomized clinical trial in obese patient. Nutr. Hosp. 2020, 34, 465-473. [CrossRef]

177. Kang, Y.M.; Lee, B.J.; Kim, J.I.; Nam, B.H.; Cha, J.Y.; Kim, Y.M.; Ahn, C.B.; Choi, J.S.; Choi, I.S.; Je, J.Y. Antioxidant effects of fermented sea tangle (Laminaria japonica) by Lactobacillus brevis BJ20 in individuals with high level of $\gamma$-GT: A randomized, double-blind, and placebo-controlled clinical study. Food Chem. Toxicol. 2012, 50, 1166-1169. [CrossRef]

178. Nishiumi, S.; Izumi, Y.; Kobayashi, T.; Yoshida, M. Possible involvement of lipids in the effectiveness of kombu in individuals with abnormally high serum triglyceride levels. J. Nutr. Sci. Vitaminol. 2020, 66, 185-190. [CrossRef]

179. Nishiumi, S.; Izumi, Y.; Kobayashi, T.; Yoshida, M. A pilot study: Effects of kombu intake on lifestyle-related diseases-possibility that kombu intake is effective in individuals with abnormally high serum triacylglycerol levels. Food Sci. Technol. Res. 2019, 25, 827-834. [CrossRef]

180. Nishimura, M.; Sugawara, M.; Kudo, M.; Kinoshita, Y.; Yoshino, H.; Nishihira, J. Effects of daily intake of Harudori-kombu: A randomized, double-blind, placebo-controlled, parallel-group study. Func. Foods Health Dis. 2019, 9, 205-223. [CrossRef]

181. Rosa, G.P.; Tavares, W.R.; Sousa, P.M.C.; Pagès, A.K.; Seca, A.M.L.; Pinto, D.C.G.A. Seaweed secondary metabolites with beneficial health effects: An overview of successes in in vitro studies and clinical trials. Mar. Drugs 2020, 18, 8. [CrossRef]

182. Afonso, N.C.; Catarino, M.D.; Silva, A.M.S.; Cardoso, S.M. Brown macroalgae as valuable food ingredients. Antioxidants 2019, 8, 365. [CrossRef]

183. Wan-Loy, C.; Siew-Moi, P. Marine algae as a potential source for anti-obesity agents. Mar. Drugs 2016, 14, 222. [CrossRef] [PubMed]

184. Hoshiyama, Y.; Sekine, T.; Sasaba, T. A case-control study of colorectal cancer and its relation to diet, cigarettes, and alcohol consumption in Saitama Prefecture, Japan. Tohoku J. Exp. Med. 1993, 171, 153-165. [CrossRef] [PubMed]

185. Minami, Y.; Kanemura, S.; Oikawa, T.; Suzuki, S.; Hasegawa, Y.; Nishino, Y.; Fujiya, T.; Miura, K. Associations of Japanese food intake with survival of stomach and colorectal cancer: A prospective patient cohort study. Cancer Sci. 2020, 111, $2558-2569$. [CrossRef]

186. Kim, J.; Lee, J.; Oh, J.H.; Chang, H.J.; Sohn, D.K.; Shin, A.; Kim, J. Associations among dietary seaweed intake, c-MYC rs6983267 polymorphism, and risk of colorectal cancer in a Korean population: A case-control study. Eur. J. Nutr. 2020, 59, 1963-1974. [CrossRef] [PubMed] 